\title{
Article \\ Geochemical Characteristics of the Lower Cretaceous Hengtongshan Formation in the Tonghua Basin, Northeast China: Implications for Depositional Environment and Shale Oil Potential Evaluation
}

\author{
Wentong $\mathrm{He}^{1,2,3} \mathbb{D}$, Youhong Sun ${ }^{1,2,4, *}$ and Xuanlong Shan ${ }^{5, *}$ \\ 1 College of Construction Engineering, Jilin University, Changchun 130021, China; hewentong0510@163.com \\ 2 National-Local Joint Engineering Laboratory of In-situ Conversion, Drilling and Exploitation Technology for \\ Oil Shale, Jilin University, Changchun 130021, China \\ 3 Key Laboratory of Oil Shale and Coexistent Energy Minerals of Jilin Province, Changchun 130061, China \\ 4 School of Engineering and Technology, China University of Geosciences, Beijing 100191, China \\ 5 College of Earth Sciences, Jilin University, Changchun 130061, China \\ * Correspondence: syh@jlu.edu.cn (Y.S.); shanxl@jlu.edu.cn (X.S.)
}

check for updates

Citation: He, W.; Sun, Y.; Shan, X. Geochemical Characteristics of the Lower Cretaceous Hengtongshan Formation in the Tonghua Basin, Northeast China: Implications for Depositional Environmen and Shale Oil Potential Evaluation. Appl. Sci. 2021, 11, 23. https://dx.doi.org/ 10.3390/app11010023

Received: 22 November 2020 Accepted: 16 December 2020 Published: 22 December 2020

Publisher's Note: MDPI stays neutral with regard to jurisdictional claims in published maps and institutional affiliations.

Copyright: () 2020 by the authors. Licensee MDPI, Basel, Switzerland. This article is an open access article distributed under the terms and conditions of the Creative Commons Attribution (CC BY) license (https: / / creativecommons.org/ licenses/by/4.0/).

\begin{abstract}
The Tonghua Basin in Northeast China potentially contains shale oil and gas resources, but the exploration and development of these resources has been limited. The Sankeyushu depression represents the sedimentary center of the Tonghua Basin, and a large thickness of shale, the Hengtongshan Formation, was deposited in this depression. Exploratory engineering discoveries in recent years have confirmed that the Hengtongshan Formation has the potential to produce oil and gas. A series of methods, including inorganic and organic geochemistry and organic petrology, have been used to study the source material, organic matter maturity, depositional environment and oil-generating potential of the Hengtongshan Formation. Investigation of drill core samples has revealed that the Hengtongshan Formation in the Sankeyushu depression is mainly composed of black shale, with a small amount of plant fossils and thin volcanic rocks, and the content of brittle minerals (quartz + carbonate minerals) is high. The provenance of organic matter in the source rocks in the Hengtongshan Formation is a mixture of aquatic organisms (algae and bacteria) and higher plants, and there may be some marine organic components present in some strata.The organic matter was deposited and preserved in a saline reducing environment. Volcanism may have promoted the formation of a reducing environment by stratification of the lake bottom water, and the lake may have experienced a short-term marine ingression with the increase in the salinity. The maturity of the organic matter in all the source rocks in the Hengtongshan Formation is relatively high, and hydrocarbons have been generated. Some source rocks may have been affected by volcanism, and the organic matter in these rocks is overmature. In terms of the shale oil resource potential, the second member of the Hengtongshan Formation is obviously superior to the other members, with an average total organic carbon (TOC) of 1.37\% and an average hydrogen index (HI) of $560.93 \mathrm{mg} \mathrm{HC} / \mathrm{g}$ TOC. Most of the samples can be classified as good to very good source rocks with good resource potential. The second member can be regarded as a potential production stratum. According to the results of geochemical analysis and observations of shale oil and natural gas during drilling, it is predicted that the shale oil is present in the form of a self-sourced reservoir, but the migration range of natural gas is likely relatively large.
\end{abstract}

Keywords: Hengtongshan Formation; shale oil; oil source input; depositional environment; resource potential; Tonghua Basin

\section{Introduction}

The Tonghua Basin, located in Northeastern China and bordering North Korea, has an area of approximately $1417.5 \mathrm{~km}^{2}$ and is an important oil and gas basin. The study area is 
located in the Sankeyushu depression within the Tonghua Basin (Figure 1). There are three sets of potential source rocks in the Tonghua Basin, namely the Yuyingzuilazi Formation, the Xiahuapidianzi Formation and the Hengtongshan Formation.

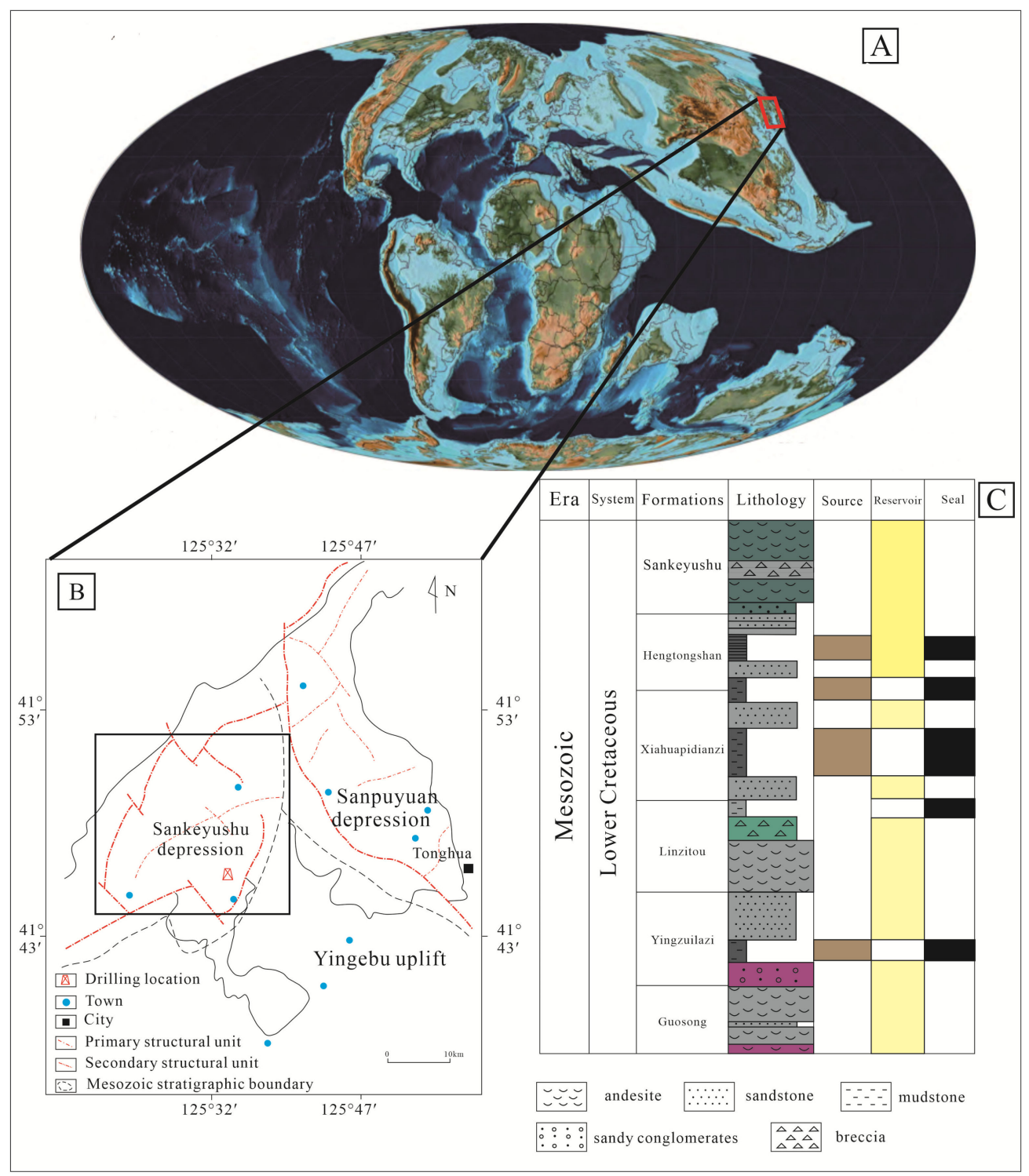

Figure 1. (A) Paleogeographic map of the Early Cretaceous. (B) Geological map of the Southeast Jilin locations. (C) Stratigraphy map of the Tonghua Basin [1].

The Sankeyushu depression is the sedimentary center of the basin and is considered to be the area with the greatest potential for oil and gas development in the Tonghua Basin. The Hengtongshan Formation in the Sankeyushu depression features a large section of mud shale [1]. In 2016, the China Geological Survey and Jilin University carried out geological surveys and drilling research in the Sankeyushu depression, during which shale oil and natural gas were found.

At present, organic geochemistry has been widely used in the study of organic matter sources, source rock types and hydrocarbon generation processes [2], but data on the organic geochemistry and petroleum geological characteristics of the Tonghua Basin are limited. Previous studies include Wang Yubo's geophysical exploration of natural resources in the Tonghua Basin in 2011 and Han Xinpeng's petroleum geology research published in 2013 [3,4]. Dandan et al. [1] and Shan et al. [5] studied hydrocarbon accumulation in the basin $[1,5]$. These studies do not provide detailed descriptions or comprehensive oil and gas 
resource evaluations of the source rock characteristics of the Hengtongshan Formation in the Tonghua Basin. At present, the Tonghua Basin is in the primary stage of exploration and development, and there is a lack of systematic research on the main hydrocarbon source rocks and the oil and gas resources in the Tonghua Basin. Detailed research is needed to guide follow-up exploration and development work to reduce the risk of economic investment. As an important petroliferous basin in Northeast China, the number of studies on the petroleum geology in the Tonghua Basin is limited, which limits the study of the entire East Asian basin and the evaluation of oil and gas resources. In this study, a highly detailed organic geochemistry study of the Hengtongshan Formation is carried out on the basis of samples obtained through drilling in the Sankeyushu depression of the Tonghua Basin, and the characteristics of the source rock, the maturity, the sedimentary environment and the shale oil resource potential in the Hengtongshan Formation are studied in detail. In addition, through the study of the source material, the sedimentary environment and the potential of shale oil and gas resources of the Hengtongshan Formation in the Late Cretaceous of the Tonghua Basin, this study provides a reference for the study of the petroleum geological characteristics of the eastern basin group around the Songliao Basin.

\section{Geological Background}

The basement of the Tonghua Basin includes two sets of Archean to Proterozoic metamorphic rock series, and the sedimentary cover strata mainly include the Middle Jurassic Houjiatun Formation and the Lower Cretaceous Guosong, Yingzuilazi, Linzitou, Xiahuapidianzi, Hengtongshan and Heiweizi Formations [6] (Figures 1 and 2). The target layer studied in this paper is the Lower Cretaceous Hengtongshan Formation, which was mainly formed under humid and warm climate conditions after volcanic activity $[7,8]$. The basin experienced a late Middle Jurassic rifting stage (deposition of the Houjiatun Formation), an early Early Cretaceous volcanic filling stage (Changliucun Formation and Guosong Formation), a late Early Cretaceous posteruption depositional stage (Yingzuilazi Formation, Xiahuapidianzi Formation and Hengtongshan Formation) and a late Cretaceous volcanic filling stage (Sankeyushu Formation) $[9,10]$.

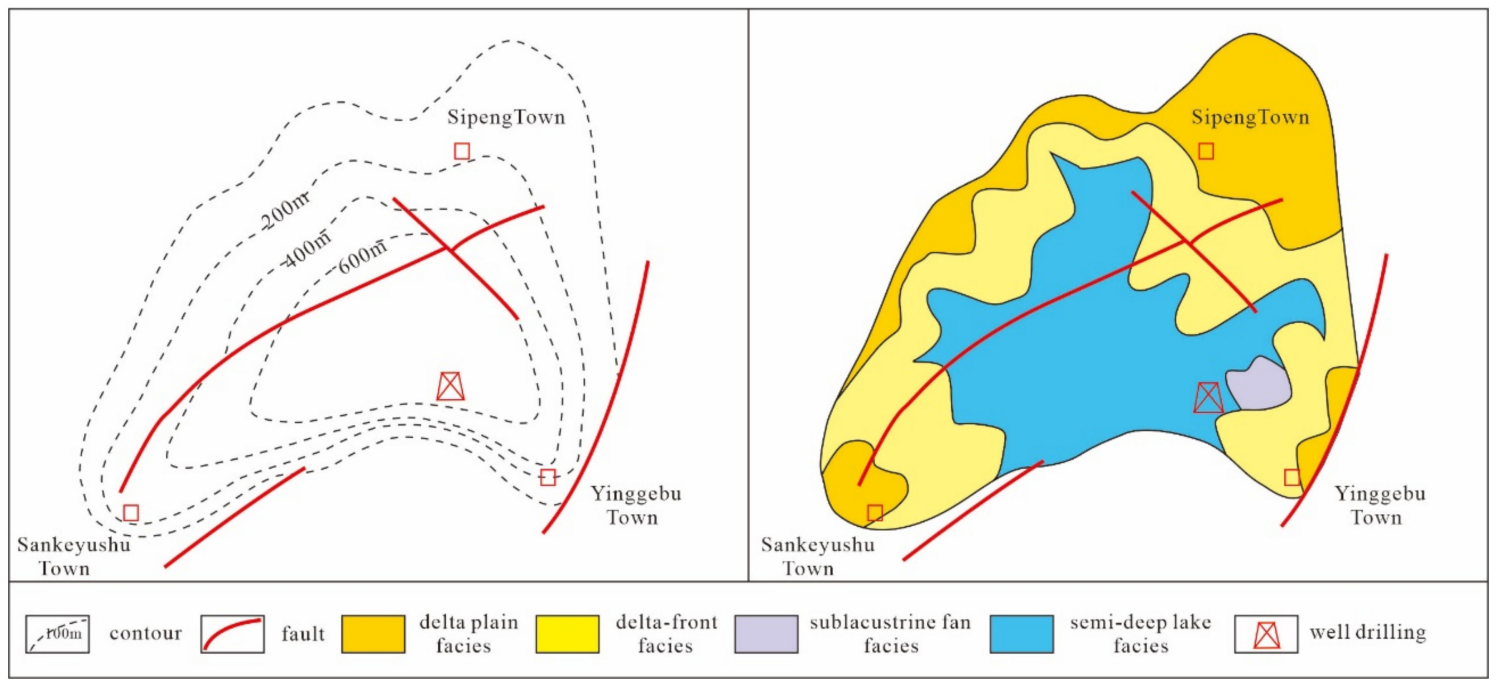

Figure 2. Stratum thickness map and sedimentary facies distribution map of the Hengtongshan Formation.

The fault structures in the basin are mainly developed in the NE and NW directions. The NE faults control the distribution of Mesozoic strata and the development of the basin, while NW faults extend to the surface and produce visible faults on the surface (Figure 1). According to the basement structure and the sedimentary characteristics of the caprock, the basin can be divided into three parts: the Sankeyushu depression, the Sanyuanpu depression and the Yingebu uplift [4]. 
The Hengtongshan Formation is widely developed in the Tonghua Basin, and its sedimentary center is in the Sankeyushu depression, where its thickness is more than $600 \mathrm{~m}$. According to the characteristics of surface outcrops and previously obtained drill cores, the Hengtongshan Formation is mainly composed of continental deposits that formed in a deep to semi-deep lake. The outer edges of the strata feature delta plain facies, delta-front facies and lake bottom fan facies, and the unit is underlain and overlain by volcanic units (Figures 2 and 3). The source rocks in the Hengtongshan Formation are mainly black shale, followed by grey black shale, mud shale and silty shale, and contain a small amount of thin-layer volcanic rocks.

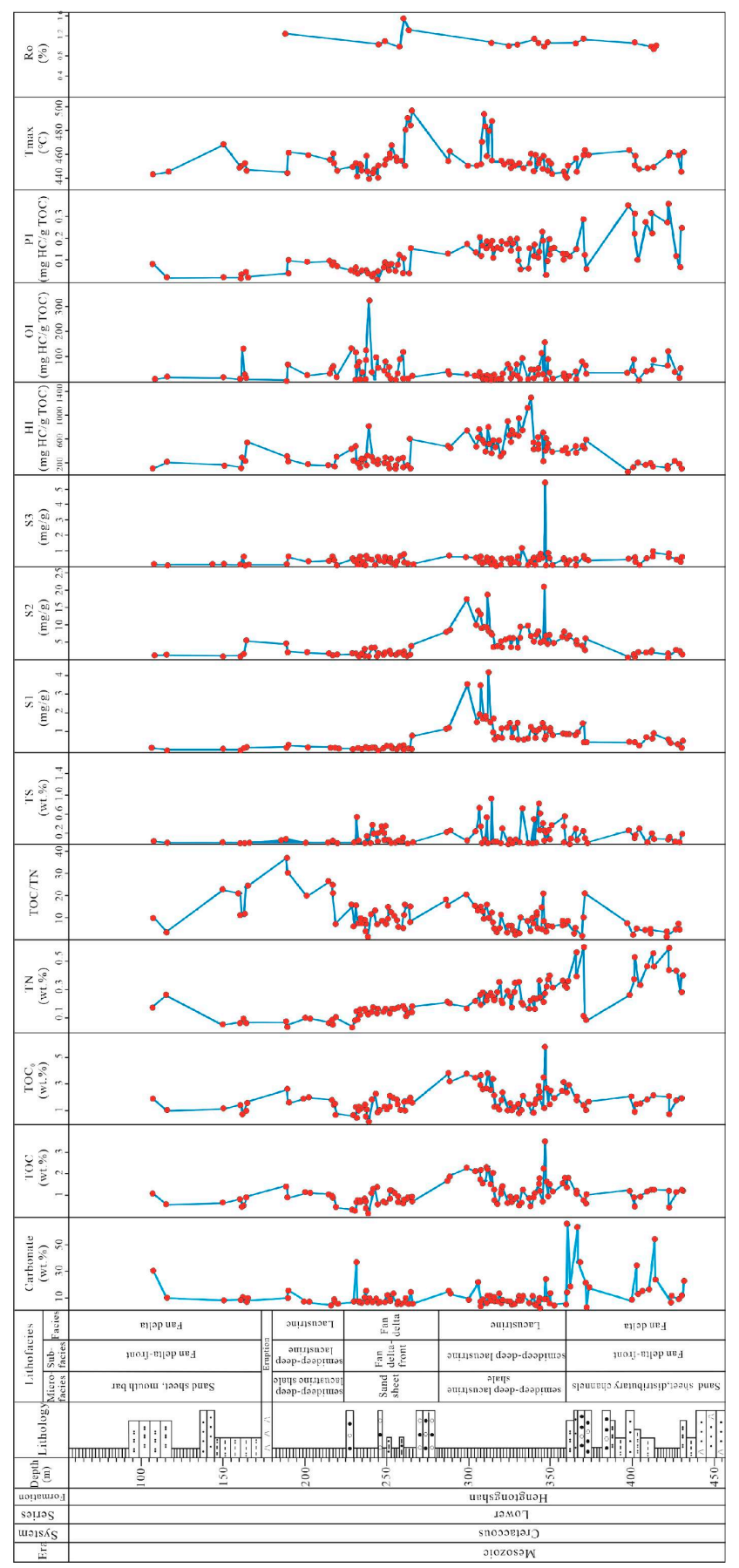

Figure 3. Map of the bulk geochemical parameters of the Hengtongshan Formation from drill cores. 


\section{Samples and Test Methods}

\subsection{Samples}

In this study, a geological survey well was drilled in the Sankeyushu depression in the thickest section of the Hengtongshan Formation, and all the strata were cored. In the process of drilling, gas logging was carried out to obtain data on the organic gas composition of the natural gas in the formation. After the geological study of all the cores, the next step involved sampling the cores.

In total, 13 representative samples were selected to observe the lithology, kerogen organic matter and vitrinite reflectance (RO), and the whole rock minerals were analyzed. Moreover, 102 source rock samples were selected for organic element analysis and rock pyrolysis experiments. In total, 32 source rock samples were extracted. The 32 organic extracts and six shale oil samples were quantitatively separated by organic family components, and 38 samples were analyzed by GC-MS and saturated hydrocarbon biomarker compounds.

\subsection{Experimental Methods}

An organic petrographic study was conducted in the Key Laboratory of Oil Shale and Coexistent Energy Minerals of Jilin Province. For the production of light sheets for the organic petrography study, a small rock sample $(20 \times 20 \times 10 \mathrm{~mm})$ was first installed in a hardening agent mixture, and the polyester resin was allowed to slowly set. After preliminary treatment, the samples were polished with a diamond grinding plate, silicon carbide paper and alumina powder. The petrographic examination used a high-power optical microscope (China) equipped with a photometry system with a fluorescent lamp. Mean random vitrinite reflectance measurements (\%, Ro) and organic maceral observations were conducted on 24 samples following ASTM Standard D7708-14 (2014).

Using a Philip-PW 1830/40-CuK $\alpha$ radiation device (Philips, Japan) $(1.54 \AA, 35 \mathrm{kV}$ and $35 \mathrm{~mA}$ ), the collected mineral data were qualitatively and quantitatively processed by X-ray diffraction (XRD) analysis at the Center for Scientific Test of Jilin University (China).

The rock samples were crushed into 200 mesh powder, the carbonate in the sample was removed with excessive dilute hydrochloric acid and the carbonate content was calculated. The total organic carbon (TOC), total nitrogen (TN) and total sulfur (TS) contents of all samples were determined by a vario PYRO cube element analyzer (Elementar, UK) and calculated according to the carbonate content at the Key Laboratory of Oil Shale and Coexistent Energy Minerals of Jilin Province following standard GBT-19145-2003.

The instrument used in the rock pyrolysis experiment analysis was a Rock Eval-6 analyzer (French Petroleum Research Institute) at the Center for Scientific Test of Jilin University (China). The parameters $\mathrm{S} 1, \mathrm{~S} 2, \mathrm{~S} 3$ and $\mathrm{T}_{\max }$ were measured, and the hydrogen index $(\mathrm{HI})$, oxygen index (OI) and production index (PI) were calculated accordingly. In these methods, the amount of pyrolyzate released from kerogen was normalized to TOC to give the HI. The temperature of maximum hydrocarbon generation $\left(\mathrm{T}_{\max }\right)$ is defined at the maximum value of the S2 peak and serves as a maturity indicator.

For the organic geochemical analysis, thirty-eight selected samples were extracted using a Soxhlet apparatus (China) with a mixture of dichloromethane and methanol (93:7). Elemental sulfur was removed by the addition of activated copper turnings. Asphaltenes were precipitated from a hexane-dichloromethane solution (80:1) and separated by centrifugation. The extracted organic matter was separated into saturated hydrocarbons, aromatic hydrocarbons and nitrogen, sulfur or oxygen (NSO) compounds by liquid chromatography. At the Key Laboratory of Oil Shale and Coexistent Energy Minerals of Jilin Province, the saturated components were dissolved in petroleum ether and analyzed by Agilent gas chromatography-mass spectrometry (Agilent Technologies Inc. USA) with an HP-5 MS elastic quartz capillary $(60 \mathrm{~m} \times 0.25 \mathrm{~mm} \times 0.25 \mathrm{~mm})$ GC column. The temperature ranged from 40 to $300{ }^{\circ} \mathrm{C}$ at a rate of $4{ }^{\circ} \mathrm{C} / \mathrm{min}$ and was then held for $30 \mathrm{~min}$ at $300^{\circ} \mathrm{C}$. The hydrocarbon fractions were subsequently analyzed by an Agilent 5975B inert MSD mass spectrometer (Agilent Technologies Inc. USA) with a gas chromatograph attached 
directly to the ion source $(70 \mathrm{eV}$ ionization voltage, $100 \mathrm{~mA}$ filament emission current, $230{ }^{\circ} \mathrm{C}$ interface temperature). Compound separation was performed on a column similar to the GC column. The saturated hydrocarbon ratios and the relative abundance of steranes and triterpanes were calculated from the integrated peak areas of the relevant ion chromatograms m/z 191 and m/z 217. The aromatic hydrocarbon ratios were also calculated from the integrated peak areas of the relevant ion chromatograms following standard GBT-30431-2013.

In the process of drilling, the abnormal presence of natural gas was detected by gas logging. The gas returned to the surface from the bit at the bottom of the well was separated from the mud by a degasser. The separated gases then entered a SK-3Q04 hydrogen flame chromatograph (Shanghai Shenkai Petroleum and Chemical Equipment, China). The total amount of natural gas and $C_{1}-C_{5}$ components were analyzed with a chromatographic analyzer every $90 \mathrm{~s}$ following standard SY/T5191-93 (technical standard of gas chromatographic logging tool).

\section{Results and Interpretation}

\subsection{Lithology}

Through the observation of the drill cores of the Hengtongshan Formation in the Tonghua Basin, it is known that the lithology of the source rock in the Hengtongshan Formation is mainly black shale, grey shale and grey silty shale. The maximum thickness of a single shale is $27.36 \mathrm{~m}$, the cumulative thickness of shale is $191 \mathrm{~m}$, and a small amount of plant fossils and thin tuff can be seen in the shale (Figure 4).

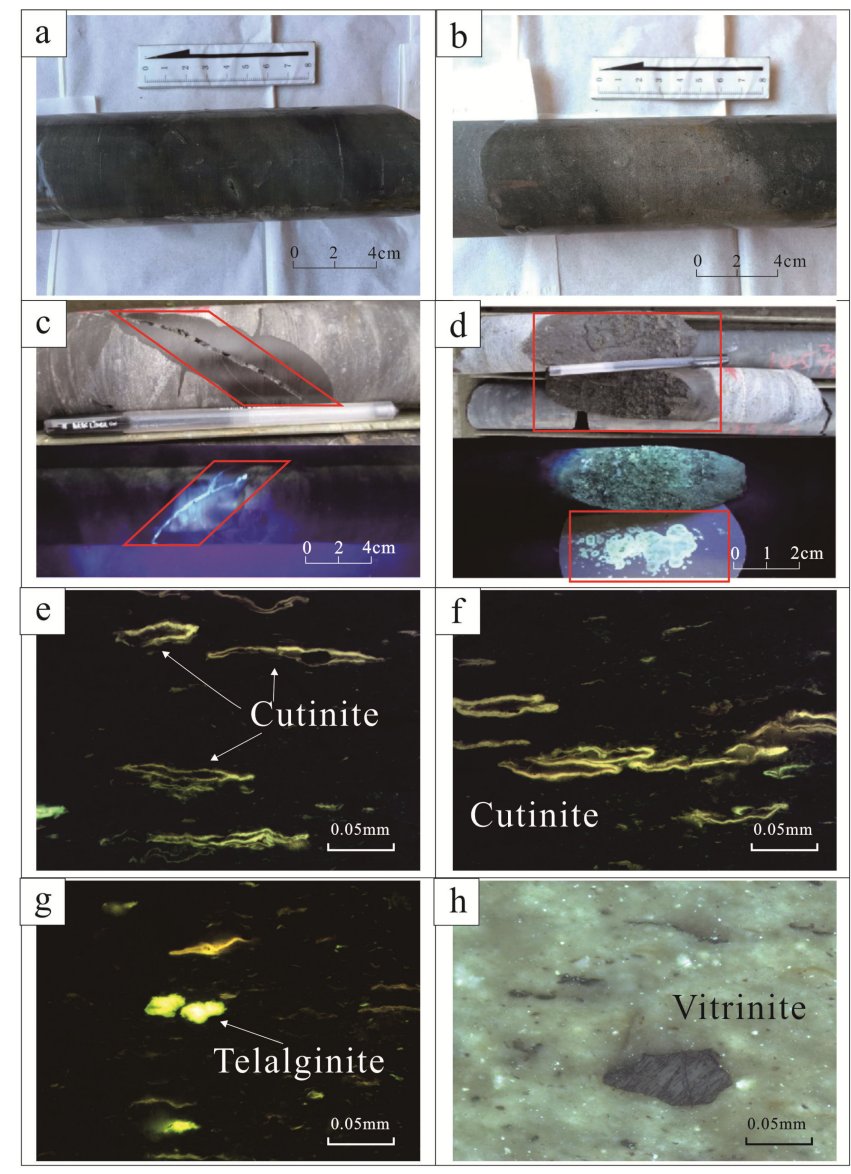

Figure 4. Photomicrographs of sediments from the Hengtongshan Formation; $(\mathbf{a}, \mathbf{b})$ are core photos; $(\mathbf{c}, \mathbf{d})$ are oil traces in rock cores under fluorescence. Oil traces are marked with red frame and show pale yellow under fluorescence; $(\mathbf{e}-\mathbf{h})$ are photos from the microscope. 


\subsection{Minerals}

The mineral and carbonate content data of the Hengtongshan Formation can be seen in Table 1. The carbonate content is between 1.91 and $65.17 \mathrm{wt} \%$, with an average of $11.65 \mathrm{wt} \%$. The average carbonate contents of the first member, second member and third member of the Hengtongshan Formation are 18.58, 12.27 and $8.96 \mathrm{wt} \%$, respectively. The overall trend is decreasing, but the differences are small. However, through targeted core observations, some samples with more than $50 \%$ carbonate content were found to be associated with carbonate dikes, resulting in high measured carbonate values. According to the XRD test, the mineral composition of the Hengtongshan Formation is primarily clay (average 38.62\%), followed by quartz (average 35.54\%, Table 1). The content of plagioclase is higher than that of K-feldspar, which is probably due to the loss of K-feldspar in the process of terrigenous clastic migration and diagenesis, and some samples feature values of less than $1 \%$ [11]. The calcite content is relatively high as a whole, with an average of $13.92 \%$, which is highly consistent with the carbonate content observed in the previous test (Tables 1 and 2).

Table 1. Parameters of the XRD results of the samples from the Hengtongshan Formation.

\begin{tabular}{|c|c|c|c|c|c|c|c|c|}
\hline Sample ID & Depth (m) & $\begin{array}{c}\text { Total Clay } \\
(w t \%)\end{array}$ & $\begin{array}{l}\text { Quartz } \\
\text { (wt \%) }\end{array}$ & $\begin{array}{l}\text { K-Feldspar } \\
\text { (wt } \%\end{array}$ & $\begin{array}{l}\text { Plagioclase } \\
\text { (wt } \%)\end{array}$ & $\begin{array}{l}\text { Calcite } \\
(w t \%)\end{array}$ & $\begin{array}{c}\text { Dolomite } \\
\text { (wt\%) }\end{array}$ & $\begin{array}{l}\text { Pyrite } \\
\text { (wt\%) }\end{array}$ \\
\hline TD1-163 & 288 & 46 & 32 & 1 & 7 & 14 & & \\
\hline TD1-171 & 278 & 43 & 37 & 2 & 7 & 11 & & \\
\hline TD1-172 & 287 & 35 & 31 & 2 & 8 & 24 & & \\
\hline TH-9 & 152.8 & 28 & 34 & 12 & 9 & 15 & 0 & 2 \\
\hline TH-34 & 224.54 & 45 & 29 & 1 & 8 & 16 & 0 & 1 \\
\hline TH-46 & 284.26 & 43 & 26 & 1 & 8 & 15 & 5 & 2 \\
\hline TH-49 & 289.06 & 41 & 35 & 12 & 2 & 7 & 2 & 1 \\
\hline TH-51 & 291.8 & 28 & 37 & 5 & 6 & 17 & 7 & 0 \\
\hline TH-76 & 331.05 & 37 & 39 & 3 & 5 & 15 & 0 & 1 \\
\hline TH-83 & 345.46 & 41 & 35 & 4 & 4 & 16 & 0 & 0 \\
\hline TH-93 & 394.33 & 43 & 42 & 4 & 2 & 9 & 0 & 0 \\
\hline TH-101 & 426.1 & 38 & 42 & 2 & 7 & 7 & 1 & 3 \\
\hline TH-102 & 426.8 & 34 & 43 & 1 & 6 & 15 & 0 & 1 \\
\hline \multicolumn{2}{|c|}{ average } & 38.62 & 35.54 & 3.85 & 6.08 & 13.92 & 1.50 & 1.10 \\
\hline
\end{tabular}


Table 2. Bulk geochemical parameters of the samples from the Hengtongshan Formation.

\begin{tabular}{|c|c|c|c|c|c|c|c|c|c|c|c|c|c|c|c|c|}
\hline \multirow[b]{2}{*}{$\begin{array}{c}\text { Sample } \\
\text { ID }\end{array}$} & \multirow{2}{*}{$\begin{array}{c}\text { Depth } \\
\text { (m) }\end{array}$} & \multirow{2}{*}{$\begin{array}{c}\text { TIC } \\
\text { (wt.\%) }\end{array}$} & \multirow{2}{*}{$\begin{array}{c}\text { TOC } \\
\text { (wt. \%) }\end{array}$} & \multirow{2}{*}{$\begin{array}{c}\text { TN } \\
\text { (wt.\%) }\end{array}$} & \multirow{2}{*}{$\begin{array}{c}\text { TS } \\
\text { (wt.\%) }\end{array}$} & \multicolumn{8}{|c|}{ Pyrolysis Data } & \multirow[b]{2}{*}{ Ro $(\%)$} & \multirow[b]{2}{*}{ TOC/TN } & \multirow[b]{2}{*}{ TOC/Ts } \\
\hline & & & & & & $\begin{array}{c}\mathrm{S} 1 \\
(\mathrm{mg} / \mathrm{g})\end{array}$ & $\begin{array}{c}\mathrm{S} 2 \\
(\mathrm{mg} / \mathrm{g})\end{array}$ & $\begin{array}{c}\text { S3 } \\
(\mathrm{mg} / \mathrm{g})\end{array}$ & $\begin{array}{c}\text { S2/S3 } \\
\text { (mg/g) }\end{array}$ & HI & OI & $\begin{array}{c}\text { PI } \\
(\mathrm{mg} / \mathrm{g})\end{array}$ & $\mathrm{T}_{\max }$ & & & \\
\hline TH-1 & 59.26 & 30.11 & 1.06 & 0.18 & 0.02 & 0.10 & 1.16 & 0.08 & 14.50 & 109.54 & 7.55 & 0.08 & 443.00 & & 5.88 & 59.57 \\
\hline TH-3 & 107.84 & 7.92 & 0.64 & 0.05 & 0.01 & 0.02 & 1.06 & 0.09 & 11.78 & 165.63 & 14.06 & 0.02 & 468.00 & & 12.80 & 86.40 \\
\hline TH-4 & 120.04 & 8.50 & 0.84 & 0.04 & 0.01 & 0.02 & 1.05 & 0.07 & 15.00 & 125.00 & 8.33 & 0.02 & 449.00 & & 21.00 & 113.40 \\
\hline TH-5 & 121.04 & 9.20 & 0.45 & 0.04 & 0.01 & 0.04 & 1.25 & 0.58 & 2.16 & 277.78 & 128.89 & 0.03 & 450.00 & & 11.25 & 60.75 \\
\hline TH-6 & 122.54 & 7.13 & 0.56 & 0.05 & 0.01 & 0.06 & 1.36 & 0.08 & 17.00 & 242.86 & 14.29 & 0.04 & 452.00 & & 11.20 & 86.80 \\
\hline TH-7 & 124.04 & 7.60 & 0.95 & 0.07 & 0.01 & 0.12 & 5.25 & 0.08 & 65.63 & 552.63 & 8.42 & 0.02 & 447.00 & & 13.57 & 147.25 \\
\hline TH-9 & 152.80 & 15.48 & 0.88 & 0.05 & 0.07 & 0.24 & 2.25 & 0.57 & 3.95 & 255.39 & 64.70 & 0.10 & 462.00 & 1.24 & 17.62 & 19.15 \\
\hline TH-10 & 166.60 & 6.10 & 1.12 & 0.10 & 0.01 & 0.18 & 1.85 & 0.26 & 7.12 & 165.18 & 23.21 & 0.09 & 460.00 & & 11.20 & 173.60 \\
\hline TH-11 & 182.47 & 4.28 & 1.05 & 0.07 & 0.01 & 0.16 & 1.55 & 0.36 & 4.31 & 147.62 & 34.29 & 0.09 & 455.00 & & 15.00 & 162.75 \\
\hline TH-12 & 184.28 & 6.18 & 0.86 & 0.06 & 0.01 & 0.13 & 1.40 & 0.45 & 3.11 & 162.41 & 52.20 & 0.08 & 460.00 & & 14.37 & 133.61 \\
\hline TH-13 & 184.30 & 7.80 & 0.98 & 0.08 & 0.03 & 0.11 & 1.33 & 0.57 & 2.33 & 135.85 & 58.22 & 0.08 & 452.00 & & 12.24 & 45.57 \\
\hline TH-14 & 186.68 & 5.16 & 0.43 & 0.10 & 0.01 & 0.09 & 1.23 & 0.09 & 13.67 & 286.05 & 20.93 & 0.07 & 447.00 & & 4.30 & 58.05 \\
\hline TH-15 & 198.12 & 6.44 & 0.34 & 0.04 & 0.01 & 0.08 & 1.50 & 0.45 & 3.33 & 441.18 & 132.35 & 0.05 & 450.00 & & 8.50 & 45.90 \\
\hline TH-16 & 199.92 & 36.49 & 0.29 & 0.08 & 0.01 & 0.08 & 1.35 & 0.35 & 3.86 & 465.52 & 120.69 & 0.06 & 452.00 & & 3.63 & 39.15 \\
\hline TH-17 & 200.62 & 7.86 & 0.70 & 0.08 & 0.52 & 0.07 & 1.46 & 0.07 & 20.86 & 208.57 & 10.00 & 0.05 & 442.00 & & 8.75 & 1.83 \\
\hline TH-18 & 202.12 & 7.30 & 0.65 & 0.15 & 0.01 & 0.06 & 1.25 & 0.40 & 3.13 & 192.31 & 61.54 & 0.05 & 450.00 & & 4.33 & 87.75 \\
\hline TH-21 & 204.50 & 6.86 & 0.68 & 0.16 & 0.01 & 0.09 & 1.80 & 0.23 & 7.83 & 264.71 & 33.82 & 0.05 & 447.00 & & 4.25 & 91.80 \\
\hline TH-22 & 206.48 & 13.86 & 0.85 & 0.16 & 0.01 & 0.12 & 2.34 & 0.10 & 23.40 & 275.29 & 11.76 & 0.05 & 446.00 & & 5.31 & 114.75 \\
\hline TH-23 & 207.20 & 7.11 & 0.68 & 0.15 & 0.04 & 0.06 & 1.17 & 0.61 & 1.92 & 171.30 & 89.31 & 0.05 & 458.00 & & 4.55 & 21.95 \\
\hline TH-24 & 207.45 & 6.29 & 0.37 & 0.14 & 0.13 & 0.05 & 1.15 & 0.45 & 2.56 & 310.81 & 121.62 & 0.04 & 445.00 & & 2.64 & 3.96 \\
\hline TH-25 & 209.10 & 8.49 & 0.14 & 0.13 & 0.01 & 0.04 & 1.12 & 0.45 & 2.49 & 800.00 & 321.43 & 0.03 & 440.00 & & 1.08 & 18.90 \\
\hline TH-26 & 211.76 & 6.52 & 1.08 & 0.15 & 0.36 & 0.09 & 3.05 & 0.36 & 8.47 & 282.41 & 33.33 & 0.03 & 445.00 & & 7.20 & 4.02 \\
\hline TH-27 & 213.39 & 7.85 & 1.34 & 0.17 & 0.20 & 0.13 & 3.13 & 0.13 & 24.08 & 233.58 & 9.70 & 0.04 & 448.00 & & 7.88 & 9.28 \\
\hline TH-28 & 215.30 & 6.19 & 0.56 & 0.14 & 0.04 & 0.05 & 1.07 & 0.55 & 1.95 & 190.39 & 97.86 & 0.04 & 441.00 & 1.04 & 4.01 & 20.34 \\
\hline TH-29 & 215.48 & 5.96 & 0.65 & 0.16 & 0.21 & 0.01 & 1.52 & 0.34 & 4.47 & 234.93 & 52.55 & 0.01 & 450.00 & & 4.04 & 4.16 \\
\hline TH-30 & 219.77 & 6.59 & 0.75 & 0.15 & 0.35 & 0.12 & 1.52 & 0.35 & 4.34 & 202.13 & 46.54 & 0.07 & 452.00 & & 5.01 & 2.90 \\
\hline TH-31 & 220.80 & 11.78 & 0.70 & 0.16 & 0.04 & 0.18 & 1.93 & 0.54 & 3.57 & 275.32 & 77.03 & 0.09 & 455.00 & 1.08 & 4.38 & 25.86 \\
\hline TH-32 & 223.50 & 6.86 & 0.84 & 0.15 & 0.04 & 0.18 & 2.23 & 0.46 & 4.85 & 266.43 & 54.96 & 0.07 & 458.00 & & 5.58 & 29.20 \\
\hline TH-33 & 223.59 & 7.66 & 1.25 & 0.15 & 0.01 & 0.12 & 2.05 & 0.25 & 8.20 & 164.00 & 20.00 & 0.06 & 460.00 & & 8.33 & 168.75 \\
\hline TH-34 & 224.54 & 12.32 & 1.18 & 0.16 & 0.01 & 0.11 & 1.29 & 0.16 & 8.06 & 109.32 & 13.56 & 0.08 & 467.00 & & 7.38 & 159.30 \\
\hline TH-35 & 227.75 & 5.02 & 1.08 & 0.17 & 0.01 & 0.07 & 1.24 & 0.11 & 11.27 & 114.81 & 10.19 & 0.05 & 457.00 & & 6.35 & 145.80 \\
\hline
\end{tabular}


Table 2. Cont.

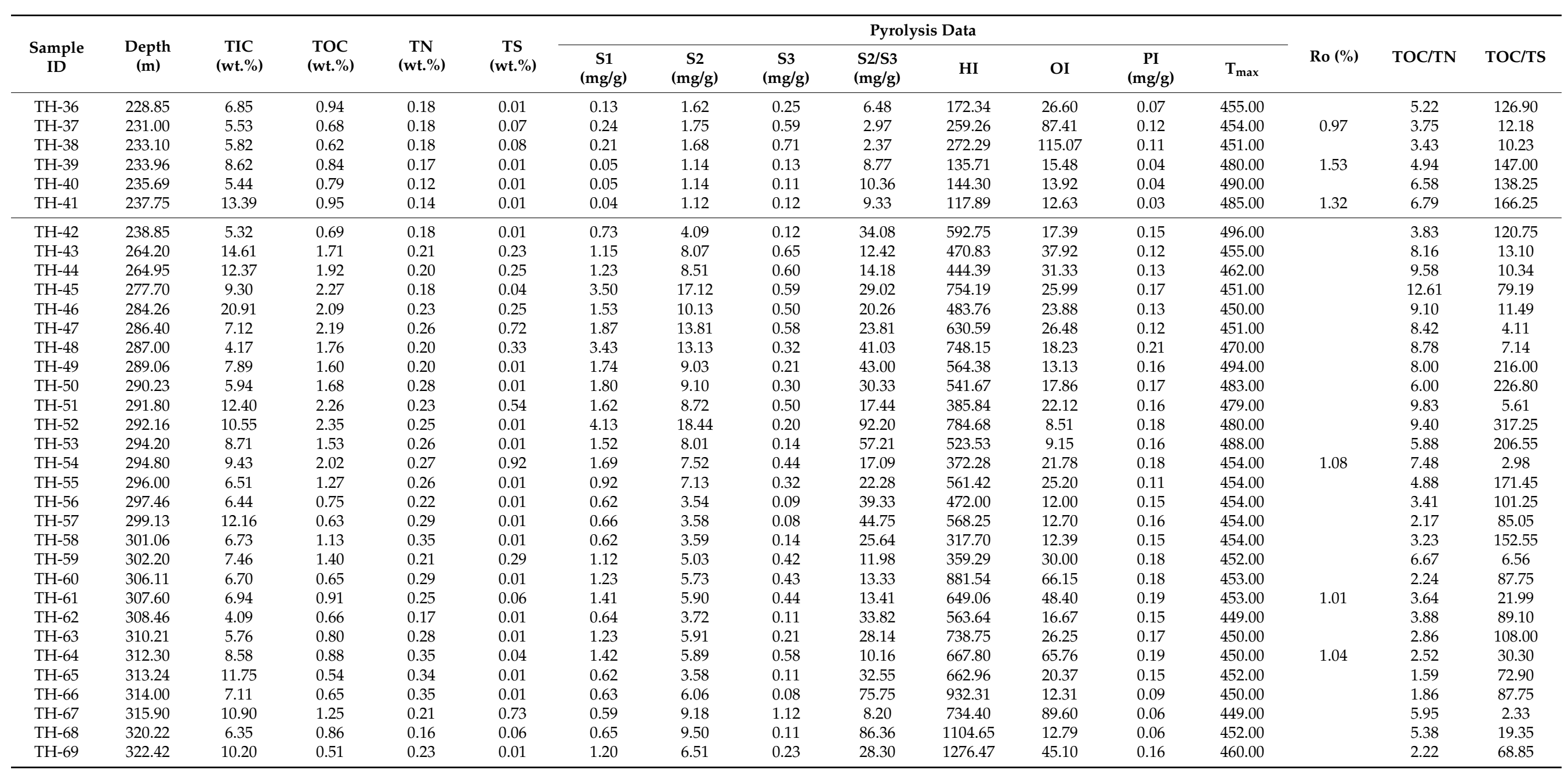


Table 2. Cont.

\begin{tabular}{|c|c|c|c|c|c|c|c|c|c|c|c|c|c|c|c|c|}
\hline \multirow[b]{2}{*}{$\begin{array}{c}\text { Sample } \\
\text { ID }\end{array}$} & \multirow[b]{2}{*}{$\begin{array}{c}\text { Depth } \\
\text { (m) }\end{array}$} & \multirow[b]{2}{*}{$\begin{array}{c}\text { TIC } \\
\text { (wt.\%) }\end{array}$} & \multirow[b]{2}{*}{$\begin{array}{c}\text { TOC } \\
\text { (wt.\%) }\end{array}$} & \multirow[b]{2}{*}{$\begin{array}{c}\text { TN } \\
\text { (wt.\%) }\end{array}$} & \multirow[b]{2}{*}{$\begin{array}{c}\text { TS } \\
\text { (wt.\%) }\end{array}$} & \multicolumn{8}{|c|}{ Pyrolysis Data } & \multirow[b]{2}{*}{ Ro (\%) } & \multirow[b]{2}{*}{ TOC/TN } & \multirow[b]{2}{*}{ TOC/TS } \\
\hline & & & & & & $\begin{array}{c}\mathrm{S} 1 \\
(\mathrm{mg} / \mathrm{g})\end{array}$ & $\begin{array}{c}\mathrm{S} 2 \\
(\mathrm{mg} / \mathrm{g})\end{array}$ & $\begin{array}{c}\text { S3 } \\
(\mathrm{mg} / \mathrm{g})\end{array}$ & $\begin{array}{c}\text { S2/S3 } \\
\text { (mg/g) }\end{array}$ & HI & OI & $\begin{array}{c}\text { PI } \\
(\mathrm{mg} / \mathrm{g})\end{array}$ & $\mathbf{T}_{\max }$ & & & \\
\hline TH-70 & 324.70 & 4.61 & 1.05 & 0.17 & 0.49 & 1.08 & 5.37 & 0.49 & 10.96 & 511.43 & 46.67 & 0.17 & 459.00 & 1.13 & 6.18 & 2.92 \\
\hline TH-72 & 327.40 & 9.42 & 1.52 & 0.23 & 0.83 & 1.09 & 7.07 & 0.47 & 15.04 & 465.13 & 30.92 & 0.13 & 453.00 & 1.08 & 6.61 & 2.47 \\
\hline TH-73 & 327.50 & 1.91 & 1.77 & 0.24 & 0.61 & 1.02 & 7.86 & 0.49 & 16.04 & 444.07 & 27.68 & 0.11 & 455.00 & 1.06 & 7.38 & 3.90 \\
\hline TH-74 & 327.60 & 7.61 & 1.24 & 0.36 & 0.25 & 1.18 & 7.63 & 0.58 & 13.16 & 615.32 & 46.77 & 0.13 & 453.00 & & 3.44 & 6.70 \\
\hline TH-75 & 330.30 & 9.06 & 0.70 & 0.22 & 0.40 & 1.41 & 4.81 & 0.77 & 6.25 & 692.09 & 110.79 & 0.23 & 458.00 & & 3.16 & 2.38 \\
\hline TH-76 & 331.05 & 23.13 & 2.18 & 0.25 & 0.25 & 1.23 & 5.19 & 0.58 & 8.95 & 238.07 & 26.61 & 0.19 & 448.00 & & 8.72 & 11.77 \\
\hline TH-78 & 332.50 & 8.47 & 1.60 & 0.33 & 0.20 & 0.71 & 6.64 & 0.09 & 73.78 & 415.00 & 5.63 & 0.10 & 447.00 & & 4.85 & 10.85 \\
\hline TH-79 & 334.20 & 13.43 & 0.93 & 0.38 & 0.07 & 1.17 & 4.71 & 0.80 & 5.89 & 506.45 & 86.02 & 0.20 & 454.00 & 1.06 & 2.45 & 18.82 \\
\hline TH-80 & 334.30 & 4.72 & 1.52 & 0.41 & 0.25 & 1.03 & 7.12 & 0.56 & 12.71 & 468.42 & 36.84 & 0.13 & 452.00 & & 3.71 & 8.21 \\
\hline TH-81 & 337.15 & 4.92 & 1.15 & 0.31 & 0.36 & 0.83 & 4.55 & 0.11 & 41.36 & 395.65 & 9.57 & 0.15 & 444.00 & & 3.71 & 4.31 \\
\hline TH-82 & 345.40 & 5.64 & 1.57 & 0.37 & 0.55 & 0.91 & 6.32 & 0.46 & 13.74 & 402.55 & 29.30 & 0.13 & 445.00 & & 4.24 & 3.88 \\
\hline TH-83 & 345.46 & 13.15 & 1.85 & 0.37 & 0.35 & 0.91 & 7.75 & 0.32 & 24.22 & 419.83 & 17.33 & 0.11 & 443.00 & & 4.99 & 7.12 \\
\hline TH-84 & 346.31 & 65.17 & 1.41 & 0.32 & 0.11 & 0.90 & 6.08 & 0.16 & 38.00 & 431.21 & 11.35 & 0.13 & 441.00 & & 4.41 & 17.30 \\
\hline TH-85 & 348.12 & 19.21 & 1.85 & 0.37 & 0.06 & 0.90 & 6.78 & 0.31 & 21.87 & 367.48 & 16.80 & 0.12 & 450.00 & & 4.99 & 41.51 \\
\hline TH-86 & 353.50 & 64.06 & 1.12 & 0.56 & 0.28 & 0.87 & 5.21 & 0.41 & 12.71 & 465.18 & 36.61 & 0.14 & 456.00 & 1.07 & 2.00 & 5.36 \\
\hline TH-87 & 353.57 & 36.84 & 1.22 & 0.39 & 0.06 & 0.79 & 4.59 & 0.09 & 51.00 & 376.23 & 7.38 & 0.15 & 446.00 & & 3.13 & 27.00 \\
\hline TH-89 & 359.50 & 3.47 & 0.66 & 0.11 & 0.08 & 0.41 & 2.83 & 0.43 & 6.58 & 428.79 & 65.15 & 0.13 & 463.00 & & 6.00 & 10.97 \\
\hline TH-90 & 360.82 & 17.11 & 1.02 & 0.08 & 0.03 & 0.42 & 5.85 & 0.35 & 16.71 & 573.53 & 34.31 & 0.07 & 460.00 & & 12.75 & 45.90 \\
\hline TH-91 & 390.43 & 7.45 & 1.25 & 0.26 & 0.25 & 0.40 & 0.75 & 0.43 & 1.74 & 60.00 & 34.40 & 0.35 & 463.00 & & 4.81 & 6.75 \\
\hline TH-92 & 394.20 & 34.48 & 0.60 & 0.37 & 0.11 & 0.38 & 0.82 & 0.51 & 1.61 & 137.82 & 85.71 & 0.32 & 458.00 & 1.06 & 1.61 & 7.44 \\
\hline TH-93 & 394.33 & 12.71 & 0.87 & 0.54 & 0.13 & 0.35 & 1.26 & 0.34 & 3.71 & 144.83 & 39.08 & 0.22 & 450.00 & & 1.61 & 8.76 \\
\hline TH-94 & 397.23 & 14.90 & 0.96 & 0.33 & 0.29 & 0.20 & 1.85 & 0.08 & 23.13 & 192.71 & 8.33 & 0.10 & 447.00 & & 2.91 & 4.53 \\
\hline TH-95 & 402.73 & 16.07 & 1.15 & 0.46 & 0.01 & 0.65 & 1.75 & 0.50 & 3.50 & 152.17 & 43.48 & 0.27 & 448.00 & & 2.50 & 155.25 \\
\hline TH-96 & 406.64 & 53.45 & 1.25 & 0.56 & 0.19 & 0.65 & 2.32 & 0.62 & 3.74 & 185.60 & 49.60 & 0.22 & 450.00 & & 2.23 & 9.02 \\
\hline TH-97 & 407.10 & 24.57 & 1.28 & 0.46 & 0.08 & 0.86 & 1.89 & 0.87 & 2.17 & 147.66 & 67.97 & 0.31 & 450.00 & 0.98 & 2.78 & 20.84 \\
\hline TH-98 & 418.00 & 6.44 & 1.24 & 0.59 & 0.07 & 0.53 & 1.44 & 0.74 & 1.95 & 116.13 & 59.68 & 0.27 & 460.00 & & 2.10 & 22.62 \\
\hline TH-99 & 418.10 & 10.97 & 0.49 & 0.44 & 0.11 & 0.39 & 0.71 & 0.58 & 1.22 & 144.90 & 118.37 & 0.35 & 461.00 & 1.06 & 1.11 & 6.01 \\
\hline TH-100 & 423.80 & 8.79 & 1.15 & 0.43 & 0.01 & 0.35 & 2.51 & 0.46 & 5.46 & 218.83 & 40.10 & 0.12 & 460.00 & & 2.67 & 154.85 \\
\hline TH-101 & 426.00 & 11.53 & 1.24 & 0.29 & 0.01 & 0.16 & 2.13 & 0.22 & 9.68 & 171.77 & 17.74 & 0.07 & 446.00 & & 4.28 & 167.40 \\
\hline TH-102 & 426.80 & 21.65 & 1.21 & 0.40 & 0.18 & 0.46 & 1.38 & 0.60 & 2.30 & 114.05 & 49.59 & 0.25 & 462.00 & 1.09 & 3.03 & 9.33 \\
\hline
\end{tabular}

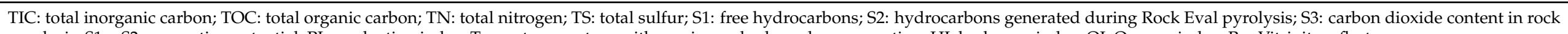
pyrolysis; S1 + S2: generative potential; PI: production index; Tmax: temperature with maximum hydrocarbon generation; HI: hydrogen index; OI: Oxygen index; Ro: Vitrinite reflectance. 


\subsection{Bulk Geochemical Parameters}

The abundance and quality of organic matter in the source rock determine the hydrocarbon generation capacity. For the quantitative characterization of the organic matter abundance, many parameters have been proposed, such as TOC, extractable organic matter (EOM) and the HI, while TOC refers to the mass percentage of organic carbon in a unit mass of rock [12,13]. According to the test, the TOC content of the first member is $0.49 \sim 1.25 \mathrm{wt} \%$ (average $1.06 \mathrm{wt} \%$ ), the TOC content of the second member is $0.63 \sim 3.49 \mathrm{wt} \%$ (average $1.38 \mathrm{wt} \%$ ), and the TOC content of the third member is $0.14 \sim 1.47 \mathrm{wt} \%$ (average $0.79 \mathrm{wt} \%$ ). The TOC value measured in this study is the residual organic matter abundance of the source rock after massive hydrocarbon expulsion. Tissot [12] stated that the organic matter abundance index of a source rock cannot be applied to a source rock with a high maturity because the initial TOC value may be much higher than the TOC measured at present [12].

$\mathrm{TN}$ is an important index in the study of the characteristics of organic matter in sedimentary rocks [14]. The TN content of the first member is $0.26-0.59 \mathrm{wt} \%$ (average $0.43 \mathrm{wt} \%$ ), that of the second member is $0.08-0.6 \mathrm{wt} \%$ (average $0.27 \mathrm{wt} \%$ ), and that of the third member is $0.05-0.26 \mathrm{wt} \%$ (average $0.12 \mathrm{wt} \%$ ). The average TS values of the first, second and third members of the Hengtongshan Formation are $0.12,0.12$ and $0.06 \mathrm{wt} \%$, respectively (Table 2).

The rock pyrolysis data for the Hengtongshan Formation are shown in Table 2. The analysis shows that the HI values of the three members of the Hengtongshan Formation are quite different; among them, the $\mathrm{HI}$ values of the second member are very high as a whole, with values of 238.07-1276.47 mg HC/g TOC and an average of $560.93 \mathrm{mg} \mathrm{HC} / \mathrm{g}$ TOC. In contrast, the average HI values of the first and third members are $247.01 \mathrm{mg} H C$. The $T_{\max }$ values of all samples are between 445 and $460{ }^{\circ} \mathrm{C}$, indicating a high maturity, but the samples with sampling depths between 233 and $238 \mathrm{~m}$ and between 287 and $294 \mathrm{~m}$ are all approximately $480{ }^{\circ} \mathrm{C}$. Combined with the geological conditions of the Tonghua Basin and the core observation results, this may be due to the short-term volcanism that enhanced the thermal maturity of the source rock $[9,10]$, resulting in over maturity of the source rocks in the two sections.

\subsection{Bitumen Bulk Geochemical Parameters}

Through the organic matter extraction experiment on the 32 source rock samples of the Hengtongshan Formation, it was found that the EOM content was relatively high, at 512.15-3589.26 mg HC/g TOC, with an average of $1490.80 \mathrm{mg} \mathrm{HC} / \mathrm{g}$ TOC, indicating good organic abundance. The results of the EOM component separation experiment on the source rock samples and six shale oil samples are shown in Table 3 and Figure 5. The EOM from the shale samples has the same characteristics as that from the shale oil samples. In these samples, the content of saturated hydrocarbons is the highest. The content of saturated hydrocarbons extracted from the shale samples is $40.01-72.3 \%$, with an average of $55.34 \%$, and the content of saturated hydrocarbons in the shale oil samples is $54.71-82.84 \%$, with an average of $69.8 \%$. The average content of aromatic hydrocarbons in the EOM from the shale samples is almost equal to the average content of NSO, with values of $21.91 \%$ and $22.75 \%$, respectively. The average content of aromatic hydrocarbons in the shale oil samples is higher than the average content of NSO, with values of $20.99 \%$ and $9.21 \%$, respectively. These indexes are widely used in hydrocarbon potential evaluations of source rocks [15]. Therefore, most of the samples from the Tonghua Basin appear to be a rich source of oil and have the potential to produce a wealth of naphthenic oil. 


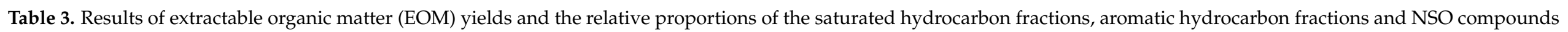
(EOM: extractable organic matter; Sat.: saturated hydrocabons; Aro.: aromatic hydrocarbons; NSO: heterocompounds; HCs.: saturated hydrocarbons + aromatic hydrocarbons).

\begin{tabular}{|c|c|c|c|c|c|c|c|c|c|c|c|c|}
\hline \multirow{2}{*}{ Sample ID } & \multirow[t]{2}{*}{ Depth (m) } & \multicolumn{5}{|c|}{$\begin{array}{l}\text { Bitumen Extraction and Chromatographic Fractions } \\
\text { (ppm of Whole Rocks) }\end{array}$} & \multirow{2}{*}{ HCs/EOM } & \multicolumn{4}{|c|}{$\begin{array}{l}\text { Chromatographic Fractions of Bitumen Extraction } \\
\text { (EOM wt.\%) }\end{array}$} & \multirow{2}{*}{$\begin{array}{c}\text { TOC } \\
\text { (wt.\%) }\end{array}$} \\
\hline & & EOM & Sat. & Aro. & NSO & HCs & & Sat./EOM & Aro./EOM & NSO/EOM & HCs & \\
\hline TS-1 & 152 & 623.11 & 285.24 & 166.73 & 171.14 & 451.97 & 0.73 & $45.78 \%$ & $26.76 \%$ & $27.47 \%$ & $72.53 \%$ & 1.47 \\
\hline TS-2 & 166.6 & 2354.70 & 1384.70 & 801.26 & 168.74 & 2185.96 & 0.93 & $58.81 \%$ & $34.03 \%$ & $7.17 \%$ & $92.83 \%$ & 1.12 \\
\hline TS-3 & 182.47 & 2215.95 & 1359.00 & 681.26 & 175.69 & 2040.26 & 0.92 & $61.33 \%$ & $30.74 \%$ & $7.93 \%$ & $92.07 \%$ & 1.05 \\
\hline TS-4 & 184.28 & 2050.95 & 1284.56 & 432.65 & 333.74 & 1717.21 & 0.84 & $62.63 \%$ & $21.10 \%$ & $16.27 \%$ & $83.73 \%$ & 0.862 \\
\hline TS-5 & 199.92 & 1642.18 & 826.32 & 201.13 & 614.73 & 1027.45 & 0.63 & $50.32 \%$ & $12.25 \%$ & $37.43 \%$ & $62.57 \%$ & 0.29 \\
\hline TS-6 & 200.62 & 1315.13 & 684.29 & 341.53 & 289.31 & 1025.82 & 0.78 & $52.03 \%$ & $25.97 \%$ & $22.00 \%$ & $78.00 \%$ & 0.7 \\
\hline TS-7 & 202.12 & 1412.64 & 570.71 & 250.95 & 590.98 & 821.66 & 0.58 & $40.40 \%$ & $17.76 \%$ & $41.84 \%$ & $58.16 \%$ & 0.758 \\
\hline TS-8 & 206.48 & 1355.67 & 729.62 & 343.53 & 282.52 & 1073.15 & 0.79 & $53.82 \%$ & $25.34 \%$ & $20.84 \%$ & $79.16 \%$ & 0.85 \\
\hline TS-9 & 207.45 & 1282.74 & 513.26 & 315.35 & 454.13 & 828.61 & 0.65 & $40.01 \%$ & $24.58 \%$ & $35.40 \%$ & $64.60 \%$ & 0.37 \\
\hline TS-10 & 209.1 & 1085.16 & 784.62 & 152.03 & 148.51 & 936.65 & 0.86 & $72.30 \%$ & $14.01 \%$ & $13.69 \%$ & $86.31 \%$ & 0.14 \\
\hline TS-11 & 215.48 & 1379.15 & 717.39 & 255.36 & 406.40 & 972.75 & 0.71 & $52.02 \%$ & $18.52 \%$ & $29.47 \%$ & $70.53 \%$ & 0.562 \\
\hline TS-12 & 219.77 & 1248.24 & 742.27 & 199.41 & 306.56 & 941.68 & 0.75 & $59.47 \%$ & $15.98 \%$ & $24.56 \%$ & $75.44 \%$ & 0.752 \\
\hline TS-13 & 223.59 & 1643.01 & 975.56 & 350.95 & 316.50 & 1326.51 & 0.81 & $59.38 \%$ & $21.36 \%$ & $19.26 \%$ & $80.74 \%$ & 1.25 \\
\hline TS-14 & 228.85 & 1422.85 & 813.73 & 458.60 & 150.52 & 1272.33 & 0.89 & $57.19 \%$ & $32.23 \%$ & $10.58 \%$ & $89.42 \%$ & 0.94 \\
\hline TS-15 & 235.69 & 1664.29 & 831.76 & 335.23 & 497.30 & 1166.99 & 0.70 & $49.98 \%$ & $20.14 \%$ & $29.88 \%$ & $70.12 \%$ & 0.79 \\
\hline TS-16 & 264.95 & 1165.22 & 645.22 & 317.43 & 202.57 & 962.65 & 0.83 & $55.37 \%$ & $27.24 \%$ & $17.38 \%$ & $82.62 \%$ & 1.915 \\
\hline TS-18 & 290.23 & 1675.00 & 918.30 & 486.07 & 270.63 & 1404.37 & 0.84 & $54.82 \%$ & $29.02 \%$ & $16.16 \%$ & $83.84 \%$ & 1.68 \\
\hline TS-19 & 292.16 & 2350.98 & 1286.23 & 651.25 & 413.50 & 1937.48 & 0.82 & $54.71 \%$ & $27.70 \%$ & $17.59 \%$ & $82.41 \%$ & 2.35 \\
\hline TS-20 & 297.46 & 1339.35 & 865.32 & 333.65 & 140.38 & 1198.97 & 0.90 & $64.61 \%$ & $24.91 \%$ & $10.48 \%$ & $89.52 \%$ & 0.75 \\
\hline TS-21 & 299.13 & 1744.25 & 926.22 & 93.28 & 724.75 & 1019.50 & 0.58 & $53.10 \%$ & $5.35 \%$ & $41.55 \%$ & $58.45 \%$ & 0.63 \\
\hline TS-22 & 301.06 & 1479.29 & 920.70 & 217.29 & 341.30 & 1137.99 & 0.77 & $62.24 \%$ & $14.69 \%$ & $23.07 \%$ & $76.93 \%$ & 1.13 \\
\hline TS-23 & 320.15 & 3589.26 & 1918.64 & 563.96 & 1106.66 & 2482.60 & 0.69 & $53.46 \%$ & $15.71 \%$ & $30.83 \%$ & $69.17 \%$ & 0.86 \\
\hline TS-24 & 345.46 & 744.25 & 326.22 & 93.28 & 324.75 & 419.50 & 0.56 & $43.83 \%$ & $12.53 \%$ & $43.63 \%$ & $56.37 \%$ & 1.846 \\
\hline TS-25 & 346.31 & 1070.15 & 656.51 & 145.65 & 267.99 & 802.16 & 0.75 & $61.35 \%$ & $13.61 \%$ & $25.04 \%$ & $74.96 \%$ & 1.41 \\
\hline TS-26 & 348.12 & 1016.11 & 617.38 & 293.71 & 105.02 & 911.09 & 0.90 & $60.76 \%$ & $28.91 \%$ & $10.34 \%$ & $89.66 \%$ & 1.845 \\
\hline TS-27 & 353.57 & 512.15 & 329.13 & 112.18 & 70.84 & 441.31 & 0.86 & $64.26 \%$ & $21.90 \%$ & $13.83 \%$ & $86.17 \%$ & 1.22 \\
\hline TS-28 & 360.82 & 984.11 & 517.36 & 368.69 & 98.06 & 886.05 & 0.90 & $52.57 \%$ & $37.46 \%$ & $9.96 \%$ & $90.04 \%$ & 1.02 \\
\hline TS-29 & 402.73 & 1011.84 & 598.40 & 258.28 & 155.16 & 856.68 & 0.85 & $59.14 \%$ & $25.53 \%$ & $15.33 \%$ & $84.67 \%$ & 1.15 \\
\hline TS-30 & 406.64 & 1554.28 & 742.27 & 264.21 & 547.80 & 1006.48 & 0.65 & $47.76 \%$ & $17.00 \%$ & $35.24 \%$ & $64.76 \%$ & 1.25 \\
\hline TS-31 & 418 & 1662.22 & 992.23 & 254.14 & 415.85 & 1246.37 & 0.75 & $59.69 \%$ & $15.29 \%$ & $25.02 \%$ & $74.98 \%$ & 0.49 \\
\hline TS-32 & 426.1 & 1721.88 & 985.75 & 418.28 & 317.85 & 1404.03 & 0.82 & $57.25 \%$ & $24.29 \%$ & $18.46 \%$ & $81.54 \%$ & 1.24 \\
\hline \multicolumn{2}{|c|}{ average } & 1490.80 & 826.58 & 325.80 & 338.42 & 1152.38 & 0.77 & 0.55 & 0.22 & 0.23 & 0.77 & 1.08 \\
\hline
\end{tabular}


Table 3. Cont.

\begin{tabular}{|c|c|c|c|c|c|c|c|c|c|c|c|c|}
\hline \multirow[t]{2}{*}{ Sample ID } & \multirow[t]{2}{*}{ Depth (m) } & \multicolumn{5}{|c|}{$\begin{array}{l}\text { Bitumen Extraction and Chromatographic Fractions } \\
\text { (ppm of Whole Rocks) }\end{array}$} & \multirow{2}{*}{ HCs/EOM } & \multicolumn{4}{|c|}{$\begin{array}{l}\text { Chromatographic Fractions of Bitumen Extraction } \\
\text { (EOM wt.\%) }\end{array}$} & \multirow{2}{*}{$\begin{array}{c}\text { TOC } \\
\text { (wt. } \%)\end{array}$} \\
\hline & & EOM & Sat. & Aro. & NSO & HCs & & Sat./EOM & Aro./EOM & NSO/EOM & HCs & \\
\hline TO-1 & 289.45 & 1339.35 & 865.32 & 333.65 & 140.38 & 1198.97 & 0.90 & $64.61 \%$ & $24.91 \%$ & $10.48 \%$ & $89.52 \%$ & \\
\hline TO-2 & 327.5 & 2350.98 & 1286.23 & 651.25 & 413.50 & 1937.48 & 0.82 & $54.71 \%$ & $27.70 \%$ & $17.59 \%$ & $82.41 \%$ & \\
\hline TO-3 & 367.7 & 1984.11 & 1517.36 & 368.69 & 98.06 & 1886.05 & 0.95 & $76.48 \%$ & $18.58 \%$ & $4.94 \%$ & $95.06 \%$ & \\
\hline $\mathrm{TO}-4$ & 387.8 & 2744.25 & 1726.22 & 593.28 & 424.75 & 2319.50 & 0.85 & $62.90 \%$ & $21.62 \%$ & $15.48 \%$ & $84.52 \%$ & \\
\hline TO-5 & 418.3 & 1756.59 & 1455.18 & 208.58 & 92.83 & 1663.76 & 0.95 & $82.84 \%$ & $11.87 \%$ & $5.28 \%$ & $94.72 \%$ & \\
\hline TO-6 & 423.2 & 2158.62 & 1668.04 & 458.22 & 32.36 & 2126.26 & 0.99 & $77.27 \%$ & $21.23 \%$ & $1.50 \%$ & $98.50 \%$ & \\
\hline \multicolumn{2}{|c|}{ average } & 2055.65 & 1419.73 & 435.61 & 200.31 & 1855.34 & 0.91 & 0.70 & 0.21 & 0.09 & 0.91 & 2055.65 \\
\hline
\end{tabular}




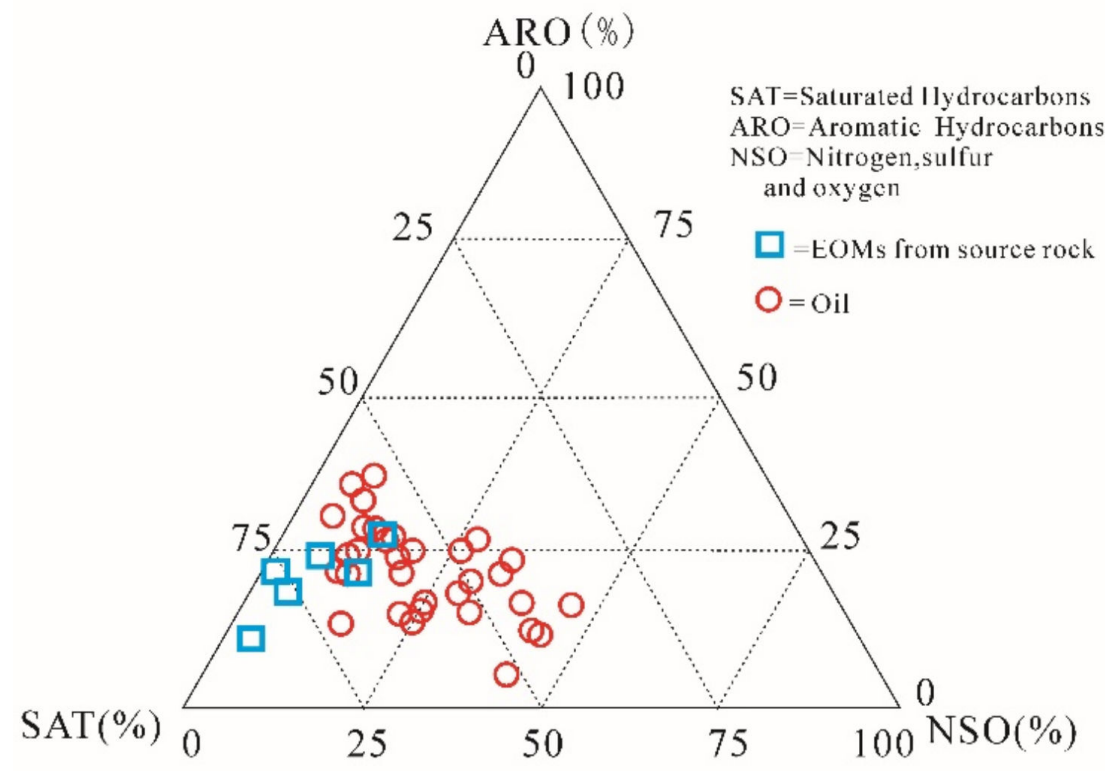

Figure 5. Ternary diagram of the extracted samples of the Hengtongshan Formation in the Tonghua Basin showing the relative proportions of saturated, aromatic and NSO components.

\subsection{Organic Geochemistry}

Biomarker compounds are widely used in organic geochemistry research and are mainly used to study the source of organic matter in sediments, organic matter maturity and paleo-depositional environments [16]. This study investigated the organic matter composition and biomarker compound characteristics of organic extracts and shale oil, such as n-alkane, isoprenoid, sterane and triterpane, from the Hengtongshan Formation shale (Figures 6 and 7; Table 4). By comparing the components of the shale extract and shale oil samples with the GC-MS test results, it was found that the organic matter composition and relative content characteristics of the two were similar. The core and drilling data reveal that the layers of shale oil production coincide with the source rock layer, so it is possible that the hydrocarbon material generated by kerogen has not undergone migration or has migrated only a short distance and remains stored directly in the source rock. 


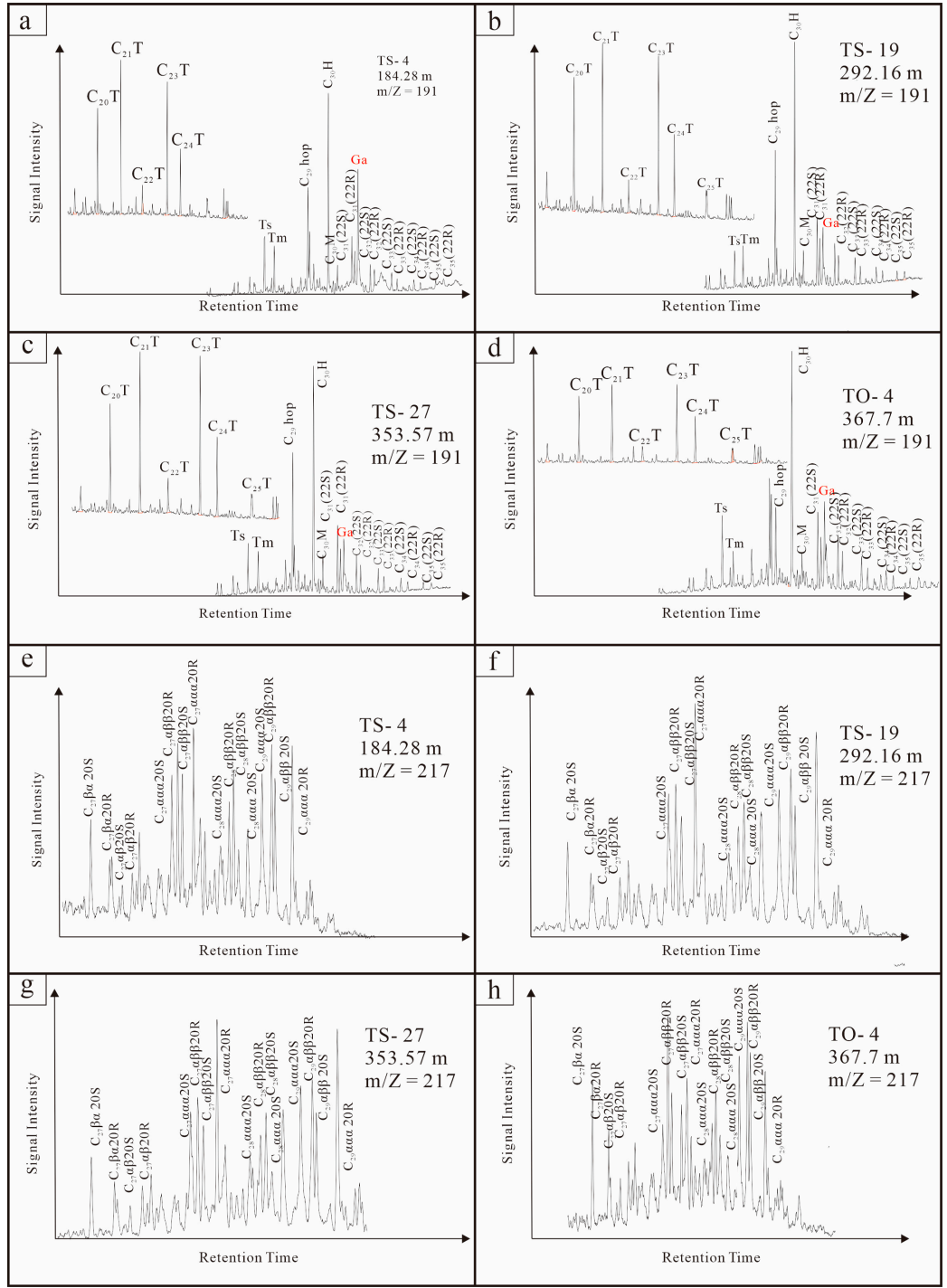

Figure 6. Gas chromatograms-mass spectrometry (TIC) (a-d) and m/z 85 mass chromatograms (e-h) of saturated hydrocarbons of the Hengtongshan Formation samples in the Tonghua Basin.

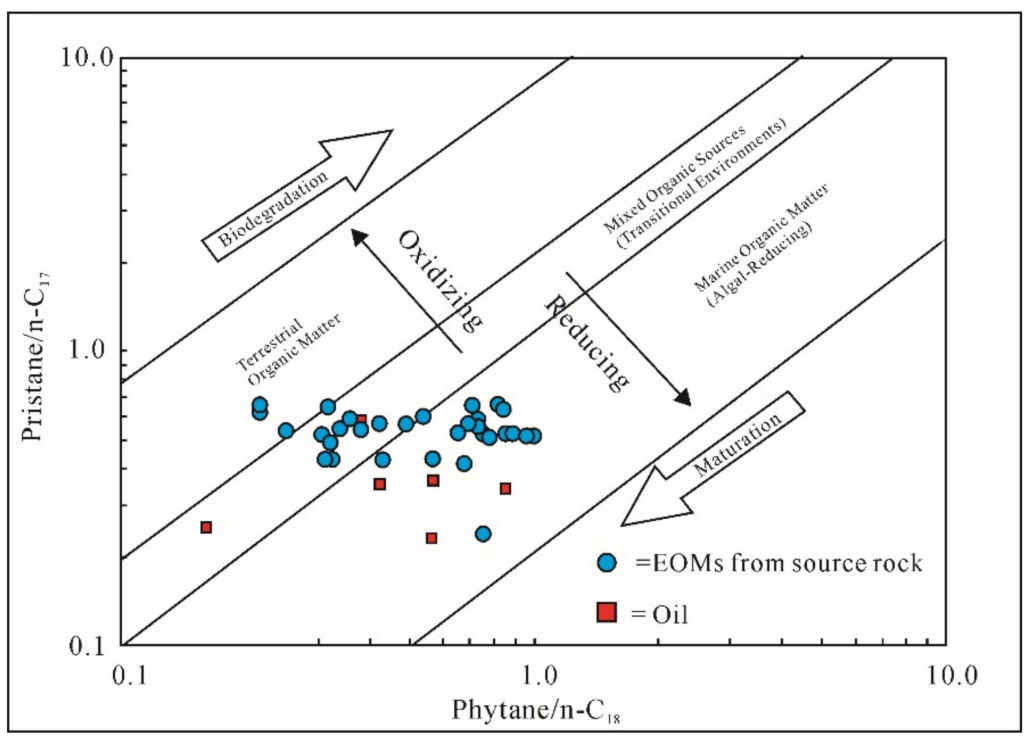

Figure 7. Cross-correlation of $\mathrm{Pr} / \mathrm{n}-\mathrm{C} 17$ and $\mathrm{Ph} / \mathrm{n}-\mathrm{C} 18$ ratios. 
Table 4. n-alkane and isoprenoid biomarker ratios.

\begin{tabular}{|c|c|c|c|c|c|c|c|c|c|c|c|c|c|c|c|c|c|c|c|}
\hline \multirow[b]{2}{*}{$\begin{array}{c}\text { Samples } \\
\text { ID }\end{array}$} & \multirow[b]{2}{*}{$\begin{array}{c}\text { Depth } \\
(\mathrm{m})\end{array}$} & \multicolumn{4}{|c|}{ n-Alkane and Isoprenoids } & \multicolumn{6}{|c|}{ Triterpanes and Terpanes $(\mathrm{m} / \mathbf{z} 191)$} & \multicolumn{6}{|c|}{ Steranes and Diasteranes $(\mathrm{m} / \mathrm{z} 217)$} & \multirow[b]{2}{*}{$\begin{array}{l}\text { Diasterane/ } \\
\text { Sterane }\end{array}$} & \multirow{2}{*}{$\begin{array}{l}\text { Sterane } \\
\text { Hopane }\end{array}$} \\
\hline & & $\mathrm{Pr} / \mathrm{Ph}$ & $\mathrm{Pr} / \mathrm{C} 17$ & $\mathrm{Ph} / \mathrm{C} 18$ & CPI & $\begin{array}{c}\mathrm{C} 3222 \mathrm{~S} / \\
(22 \mathrm{~S}+22 \mathrm{R})\end{array}$ & C29/C30 & $\mathrm{C} 31 \mathrm{R} / \mathrm{C} 30 \mathrm{H}$ & С $30 \mathrm{M} / \mathrm{C} 30 \mathrm{H}$ & $\mathrm{Ga} / \mathrm{C} 30 \mathrm{H}$ & $\mathrm{Ts} /(\mathrm{Ts}+\mathrm{Tm})$ & $\begin{array}{c}\mathrm{C} 2920 \mathrm{~S} / \\
(20 \mathrm{~S}+20 \mathrm{R})\end{array}$ & $\begin{array}{c}C 29 \beta \beta / \\
(\alpha \alpha+\beta \beta)\end{array}$ & C27/C29 & Regu & $\mathrm{r}$ Ster & $\begin{array}{l}(\%) \\
\text { C29 }\end{array}$ & & \\
\hline TS-1 & 152.00 & 0.78 & 0.51 & 0.76 & 1.06 & 0.61 & 0.45 & 0.18 & 0.16 & 0.42 & 0.85 & 0.35 & 0.45 & 0.50 & 0.28 & 0.15 & 0.56 & 0.56 & 0.32 \\
\hline TS-2 & 166.60 & 0.85 & 0.43 & 0.56 & 1.04 & 0.53 & 0.51 & 0.18 & 0.14 & 0.51 & 0.86 & 0.31 & 0.53 & 0.90 & 0.35 & 0.26 & 0.39 & 0.71 & 0.33 \\
\hline TS-3 & 182.47 & 0.76 & 0.56 & 0.69 & 1.10 & 0.59 & 0.42 & 0.18 & 0.13 & 0.40 & 0.62 & 0.32 & 0.53 & 0.50 & 0.27 & 0.20 & 0.53 & 0.66 & 0.21 \\
\hline TS-4 & 184.28 & 0.77 & 0.52 & 0.85 & 1.11 & 0.63 & 0.46 & 0.16 & 0.14 & 0.53 & 0.73 & 0.38 & 0.56 & 0.43 & 0.26 & 0.13 & 0.61 & 0.65 & 0.46 \\
\hline TS-5 & 199.92 & 0.92 & 0.55 & 0.71 & 1.12 & 0.52 & 0.48 & 0.19 & 0.14 & 0.41 & 0.77 & 0.36 & 0.52 & 0.47 & 0.25 & 0.22 & 0.53 & 0.82 & 0.30 \\
\hline TS-6 & 200.62 & 0.76 & 0.41 & 0.67 & 1.03 & 0.60 & 0.50 & 0.15 & 0.14 & 0.40 & 0.73 & 0.46 & 0.53 & 0.50 & 0.26 & 0.21 & 0.52 & 0.65 & 0.35 \\
\hline TS-7 & 202.12 & 0.70 & 0.52 & 0.93 & 1.06 & 0.58 & 0.49 & 0.15 & 0.14 & 0.32 & 0.55 & 0.32 & 0.46 & 0.72 & 0.33 & 0.22 & 0.46 & 0.96 & 0.32 \\
\hline TS-8 & 206.48 & 0.75 & 0.24 & 0.74 & 1.06 & 0.54 & 0.45 & 0.17 & 0.13 & 0.35 & 0.83 & 0.42 & 0.48 & 0.83 & 0.37 & 0.19 & 0.44 & 0.92 & 0.51 \\
\hline TS-9 & 207.45 & 0.65 & 0.60 & 0.53 & 1.10 & 0.60 & 0.44 & 0.18 & 0.13 & 0.37 & 0.45 & 0.46 & 0.55 & 0.48 & 0.26 & 0.20 & 0.54 & 1.03 & 0.31 \\
\hline TS-10 & 209.10 & 0.80 & 0.52 & 0.86 & 1.08 & 0.53 & 0.45 & 0.20 & 0.13 & 0.43 & 0.73 & 0.32 & 0.42 & 0.54 & 0.27 & 0.22 & 0.51 & 1.21 & 0.24 \\
\hline TS-11 & 215.48 & 0.89 & 0.58 & 0.35 & 1.09 & 0.57 & 0.51 & 0.17 & 0.15 & 0.75 & 0.89 & 0.30 & 0.47 & 0.72 & 0.33 & 0.21 & 0.46 & 1.25 & 0.38 \\
\hline TS-12 & 219.77 & 0.54 & 0.53 & 0.65 & 1.08 & 0.51 & 0.54 & 0.20 & 0.13 & 0.64 & 0.84 & 0.35 & 0.46 & 0.85 & 0.36 & 0.22 & 0.42 & 0.86 & 0.23 \\
\hline TS-13 & 223.59 & 0.74 & 0.63 & 0.82 & 1.09 & 0.53 & 0.52 & 0.21 & 0.13 & 0.48 & 0.72 & 0.30 & 0.48 & 0.79 & 0.35 & 0.21 & 0.44 & 0.80 & 0.24 \\
\hline TS-14 & 228.85 & 0.79 & 0.51 & 0.97 & 1.01 & 0.55 & 0.53 & 0.24 & 0.13 & 0.33 & 0.80 & 0.38 & 0.53 & 0.51 & 0.26 & 0.22 & 0.52 & 0.88 & 0.34 \\
\hline TS-15 & 235.69 & 0.75 & 0.64 & 0.70 & 1.02 & 0.58 & 0.51 & 0.19 & 0.14 & 0.25 & 0.47 & 0.38 & 0.43 & 0.73 & 0.34 & 0.20 & 0.46 & 0.75 & 0.27 \\
\hline TS-16 & 264.95 & 0.69 & 0.60 & 0.72 & 1.15 & 0.57 & 0.52 & 0.19 & 0.14 & 0.26 & 0.53 & 0.33 & 0.43 & 0.39 & 0.23 & 0.19 & 0.58 & 0.75 & 0.31 \\
\hline TS-17 & 287.00 & 0.72 & 0.52 & 0.73 & 1.06 & 0.52 & 0.49 & 0.18 & 0.14 & 0.22 & 0.61 & 0.38 & 0.46 & 0.46 & 0.24 & 0.24 & 0.52 & 0.97 & 0.38 \\
\hline TS-18 & 290.23 & 0.55 & 0.65 & 0.81 & 1.06 & 0.59 & 0.50 & 0.18 & 0.14 & 0.24 & 0.55 & 0.30 & 0.44 & 0.51 & 0.27 & 0.20 & 0.53 & 0.75 & 0.26 \\
\hline TS-19 & 292.16 & 0.66 & 0.51 & 0.30 & 1.13 & 0.53 & 0.42 & 0.20 & 0.12 & 0.33 & 0.56 & 0.43 & 0.53 & 0.47 & 0.25 & 0.21 & 0.54 & 1.16 & 0.17 \\
\hline TS-20 & 297.46 & 0.63 & 0.56 & 0.49 & 1.08 & 0.59 & 0.48 & 0.20 & 0.15 & 0.22 & 0.46 & 0.45 & 0.43 & 0.66 & 0.31 & 0.23 & 0.47 & 0.95 & 0.13 \\
\hline TS-21 & 299.13 & 0.78 & 0.54 & 0.34 & $\begin{array}{l}1.10 \\
\text { S }\end{array}$ & 0.63 & 0.39 & 0.21 & 0.11 & 0.34 & 0.77 & 0.41 & 0.54 & 0.64 & 0.31 & 0.21 & 0.49 & $\begin{array}{l}1.29 \\
\text { S }\end{array}$ & 0.17 \\
\hline TS-22 & 301.06 & 0.80 & 0.56 & 0.42 & 1.18 & 0.54 & 0.49 & 0.21 & 0.12 & 0.33 & 0.84 & 0.48 & 0.57 & 0.78 & 0.33 & 0.25 & 0.42 & 0.95 & 0.26 \\
\hline TS-25 & 346.31 & 0.76 & 0.56 & 0.38 & 1.11 & 0.57 & 0.41 & 0.25 & 0.16 & 0.58 & 0.75 & 0.44 & 0.48 & 0.79 & 0.33 & 0.24 & 0.43 & 1.19 & 0.11 \\
\hline TS-26 & 348.12 & 0.91 & 0.49 & 0.32 & 1.17 & 0.58 & 0.44 & 0.26 & 0.14 & 0.57 & 0.79 & 0.35 & 0.53 & 0.70 & 0.32 & 0.21 & 0.46 & $\begin{array}{l}1.21 \\
\text { S }\end{array}$ & 0.32 \\
\hline TS-27 & 353.57 & 0.68 & 0.42 & 0.43 & 1.08 & 0.58 & 0.41 & 0.30 & 0.13 & 0.60 & 0.85 & 0.33 & 0.52 & 0.72 & 0.33 & 0.20 & 0.46 & $\begin{array}{l}1.42 \\
\text { L }\end{array}$ & 0.19 \\
\hline TS-28 & 360.82 & 0.89 & 0.62 & 0.22 & $\begin{array}{l}1.09 \\
\text {. }\end{array}$ & 0.58 & 0.44 & 0.29 & 0.13 & 0.63 & 0.58 & 0.38 & 0.58 & 0.88 & 0.36 & 0.23 & 0.41 & 1.61 & 0.12 \\
\hline TS-29 & 402.73 & 0.91 & 0.43 & 0.32 & 1.07 & 0.60 & 0.42 & 0.29 & 0.13 & 0.46 & 0.63 & 0.34 & 0.52 & 1.07 & 0.38 & 0.27 & 0.35 & 1.25 & 0.23 \\
\hline TS-30 & 406.64 & 0.76 & 0.53 & 0.25 & 1.08 & 0.59 & 0.41 & 0.33 & 0.12 & 0.39 & 0.79 & 0.33 & 0.55 & 0.70 & 0.34 & 0.18 & 0.48 & 1.86 & 0.31 \\
\hline TS-31 & 418.00 & 0.76 & 0.64 & 0.22 & 1.08 & 0.56 & $\begin{array}{l}0.41 \\
0.46\end{array}$ & 0.32 & 0.16 & 0.33 & 0.84 & 0.38 & 0.63 & 1.15 & $\begin{array}{l}0.07 \\
0.39\end{array}$ & $\begin{array}{l}0.10 \\
0.28\end{array}$ & $\begin{array}{l}0.40 \\
0.34\end{array}$ & $\begin{array}{l}1.00 \\
1.29\end{array}$ & 0.21 \\
\hline TS-32 & 426.10 & 0.75 & 0.63 & 0.32 & 1.06 & 0.52 & 0.43 & 0.32 & 0.15 & 0.32 & 0.75 & 0.35 & 0.42 & 0.83 & 0.34 & 0.24 & 0.42 & 1.61 & 0.32 \\
\hline TO-1 & 289.45 & 0.61 & 0.34 & 0.85 & 1.17 & 0.55 & 0.46 & 0.22 & 0.11 & 0.23 & 0.70 & 0.39 & 0.35 & 0.58 & 0.30 & 0.18 & 0.52 & 1.16 & 0.18 \\
\hline TO-2 & 327.50 & 0.84 & 0.36 & 0.56 & 1.07 & 0.58 & 0.45 & 0.17 & 0.18 & 0.28 & 0.55 & 0.46 & 0.44 & 0.73 & 0.32 & 0.25 & 0.43 & 1.25 & 0.22 \\
\hline TO-3 & 367.70 & 0.72 & 0.23 & 0.56 & 1.12 & 0.59 & 0.38 & 0.25 & 0.19 & 0.32 & 0.76 & 0.45 & 0.43 & 0.83 & 0.42 & 0.09 & 0.50 & 1.54 & 0.25 \\
\hline TO-4 & 387.80 & 0.66 & 0.35 & 0.42 & 1.18 & 0.52 & 0.45 & 0.22 & 0.14 & 0.26 & 0.68 & 0.51 & 0.48 & 0.61 & 0.29 & 0.22 & 0.48 & 1.25 & 0.17 \\
\hline TO-5 & 418.30 & 0.81 & 0.54 & 0.38 & 1.15 & 0.64 & 0.45 & 0.30 & 0.13 & 0.56 & 0.83 & 0.43 & 0.49 & 0.74 & 0.36 & 0.16 & 0.48 & 1.68 & 0.16 \\
\hline TO-6 & 423.20 & 0.73 & 0.25 & 0.16 & 1.17 & 0.67 & 0.44 & 0.33 & 0.19 & 0.25 & 0.64 & 0.45 & 0.46 & 0.73 & 0.38 & 0.10 & 0.52 & 1.64 & 0.32 \\
\hline
\end{tabular}




\subsection{1. n-Alkanes and Isoprenoids}

The distribution of $\mathrm{n}$-alkanes in the Hengtongshan Formation samples shows that low to medium molecular weight compounds $\left(n-C_{13}-n-C_{23}\right)$ are dominant, and there are significant waxy alkanes $\left(+n-C_{23}\right)$, mainly with odd carbon numbers, thus yielding a medium carbon preference index (CPI) (Figure 6; Table 4). The distribution of alkanes in the samples is similar to that of a large number of long-chain alkanes present in algae or plants $[17,18]$ The same conclusion was reached based on kerogen microscopy observations of the source rock in the Hengtongshan Formation because a large amount of alginite and amorphous organic matter can be seen under the microscope (Figure 4).

In the study of biomarkers, pristine (Pr) and phytane $(\mathrm{Ph})$ are often detected, and their concentrations are very important for environmental research $[19,20]$. The acyclic isoprenoids $\mathrm{Pr}$ and $\mathrm{Ph}$ were found in all samples from the Hengtongshan Formation (Figure 6a-d). The ratio of Pr to Ph has been widely used as a redox condition parameter in sedimentary environment research [21]. Previous studies have shown that $\mathrm{Pr} / \mathrm{Ph}$ ratios below 0.6 indicate anoxic conditions, ratios between 0.6 and 3.0 indicate sub-oxic conditions, and ratios above 3.0 indicate oxic conditions [22]. By testing 38 samples from the source rocks of the Hengtongshan Formation, the $\mathrm{Pr} / \mathrm{Ph}$ ratios are 0.54 to 0.92 (average 0.76), which indicates that the sedimentary environment of the organic matter featured sub-oxic conditions, which are conducive to the preservation of organic matter.

The relationship between $\mathrm{Pr} / \mathrm{n}-\mathrm{C}_{17}$ and $\mathrm{Ph} / \mathrm{n}-\mathrm{C}_{18}$ is often used to study the source of organic matter and the sedimentary paleoenvironment of source rocks [23-26]. In this study, it was found that the $\mathrm{Pr} / \mathrm{n}-\mathrm{C}_{17}$ and $\mathrm{Ph} / \mathrm{n}-\mathrm{C}_{18}$ values are $0.23-0.64$ (average 0.50 ) and $0.16-0.93$ (average 0.54 ), respectively. The overall numerical fluctuation is relatively small, and the data indicate that the source rock of the Hengtongshan Formation was deposited under reducing conditions and that the material was from a mixed source $[27,28]$ (Figure 7; Table 3); however, additional analysis is needed to determine the specific components.

\subsubsection{Hopanoids and Steroids}

In this study, the m/Z 191 mass chromatogram features are basically similar. The relative abundance of hopanes is higher than that of tricyclic terpanes (Figure 8a-d). The $\mathrm{C}_{29} / \mathrm{C}_{30} 17 \mathrm{a}(\mathrm{H})$ hopane ratios of the samples are between 0.38 and 0.54 (average 0.46; Table 3). Previous studies have suggested that this is a typical feature of clastic source sedimentary rocks $[29,30]$.

As the molecular energy of Ts $18 \mathrm{a}(\mathrm{H})$-trisnorhopane is higher than that of $\mathrm{Tm} 17 \mathrm{a}(\mathrm{H})$ trisnorhopane, the stability of Ts is higher than that of Tm. With the increase in maturity, the value of $\mathrm{Ts} /(\mathrm{Ts}+\mathrm{Tm})$ increases gradually [31]. The Ts $/(\mathrm{Ts}+\mathrm{Tm})$ values of the samples are between 0.46 and 0.89 (average 0.70 ), reflecting the high thermal maturity of the source rock (Table 4). Previous studies have also shown that with the increase in the organic matter maturity, the ratio of $C_{30}$ moretane $/ C_{30}$ hopane $\left(C_{30} \mathrm{M} / \mathrm{C}_{30} \mathrm{H}\right.$, moretane/hopane) decreases from 0.8 to below 0.1 [16]. The $\mathrm{C}_{30} \mathrm{M} / \mathrm{C}_{30} \mathrm{H}$ values of these samples are between 0.11 and 0.19 (average 0.14), reflecting a high thermal maturity (Table 4).

The $\mathrm{C}_{31} \mathrm{R} / \mathrm{C}_{30} \mathrm{H}$ hopane ratio is used to distinguish marine and lake environments. The $\mathrm{C}_{31} \mathrm{R} / \mathrm{C}_{30} \mathrm{H}$ hopane ratios of organic matter in marine environments are generally higher than 0.25 , but the ratio of organic matter in lake environments is generally lower [16]. The $\mathrm{C}_{31} \mathrm{R} / \mathrm{C}_{30} \mathrm{H}$ hopane ratios of the extracts from the Hengtongshan Formation range from 0.15 to 0.33 (average 0.22). According to the lithofacies results of the Hengtongshan Formation samples, the strata feature the characteristics of continental lakes, so the lake environment may have been invaded by sea water. The cross plot of the $C_{31} R / C_{30} H$ hopane ratio parameter and $\mathrm{Pr} / \mathrm{Ph}$ ratio (Figure 9) supports this conclusion. 


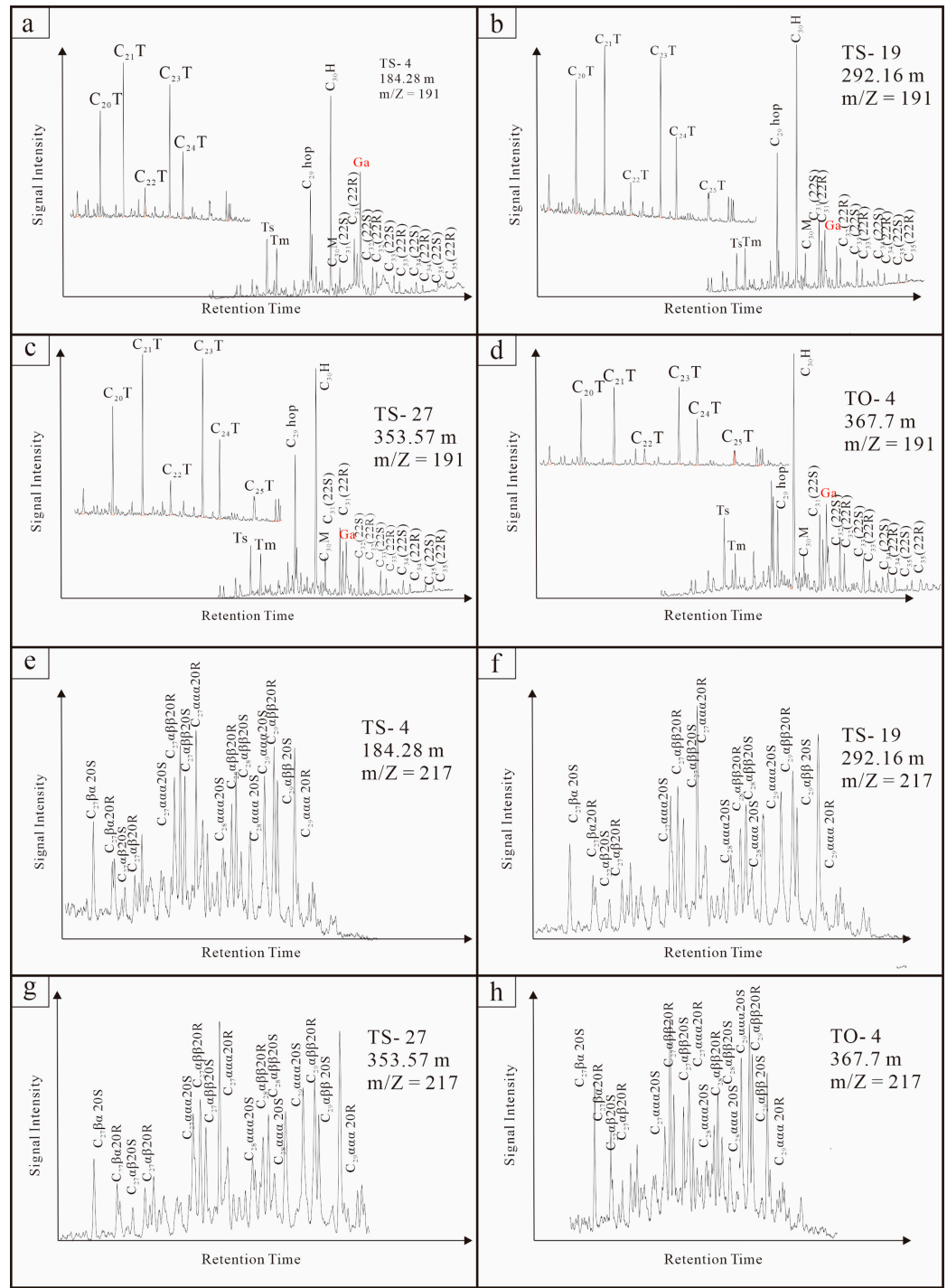

Figure 8. The $\mathrm{m} / \mathrm{z} 191(\mathbf{a}-\mathbf{d})$ and $\mathrm{m} / \mathrm{z} 217$ (e-h) mass chromatogram of saturated hydrocarbons of the Hengtongshan Formation samples in the Tonghua Basin.

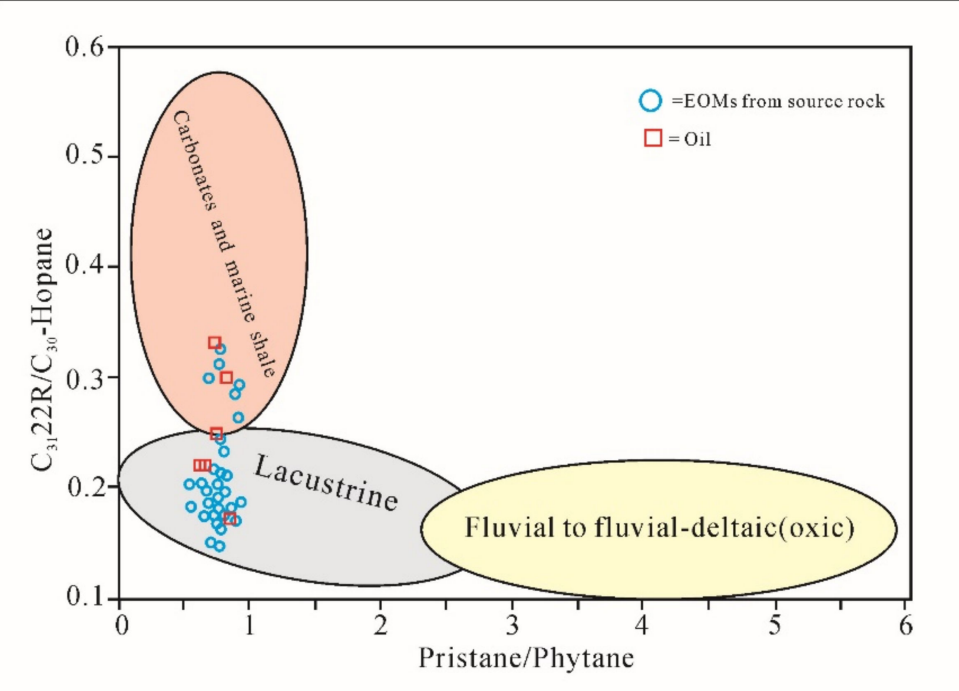

Figure 9. Hopane and isoprenoid ratios of the extracted oil samples, adapted from [16]. 
Gammacerane was initially considered to be a high-salinity indicator [32]. It is also thought to be related to increases in salinity in marine and lacustrine environments [21]. The gammacerane index ( $\mathrm{GI}=$ gammacerane $/ \alpha \beta \mathrm{C}_{30}$ hopane) of the extracted samples of the Hengtongshan Formation reflects a high-salinity, reducing environment [16] (Figures 8a-d and 10).

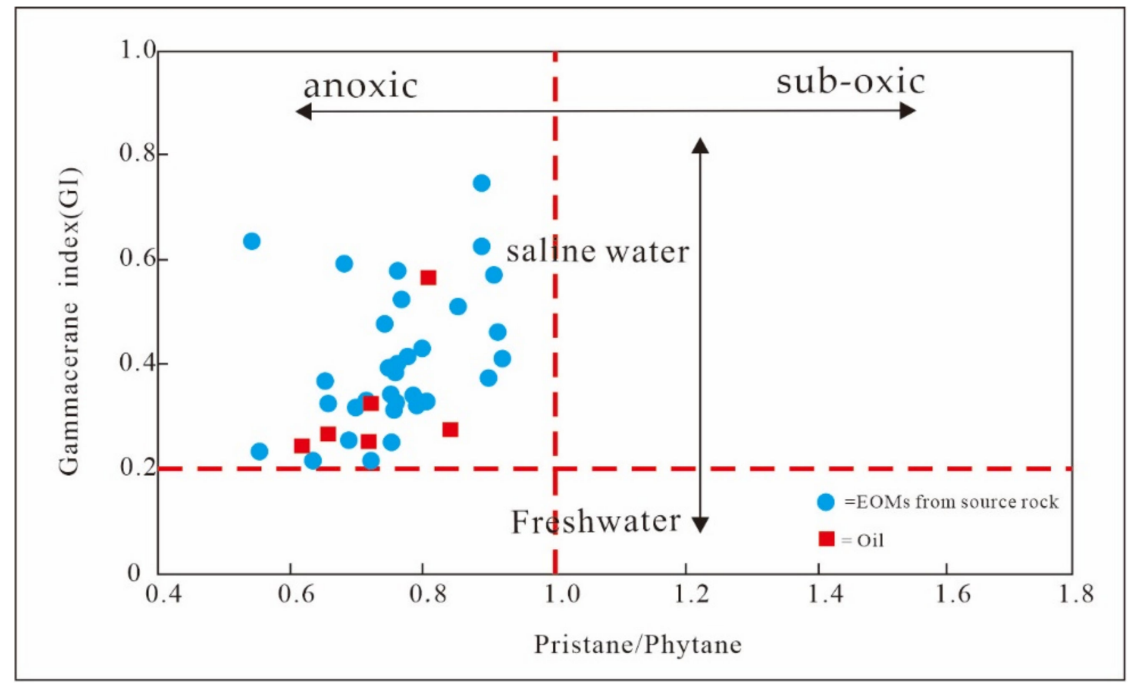

Figure 10. Plot of the Gammacerane index and Pristane/Phytane of the extracted oil samples, adapted from [16].

In this study, the $\mathrm{m} / \mathrm{Z} 217$ mass chromatogram of saturated hydrocarbons in 38 samples from the Hengtongshan Formation shows a series of distributions of diastereanes and steroids. Among these compounds are conventional steroids C27, C28 and C29, which are related to the source of the parent materials of organic matter (Figures $8 \mathrm{e}-\mathrm{h}$ and 11; Table 4).

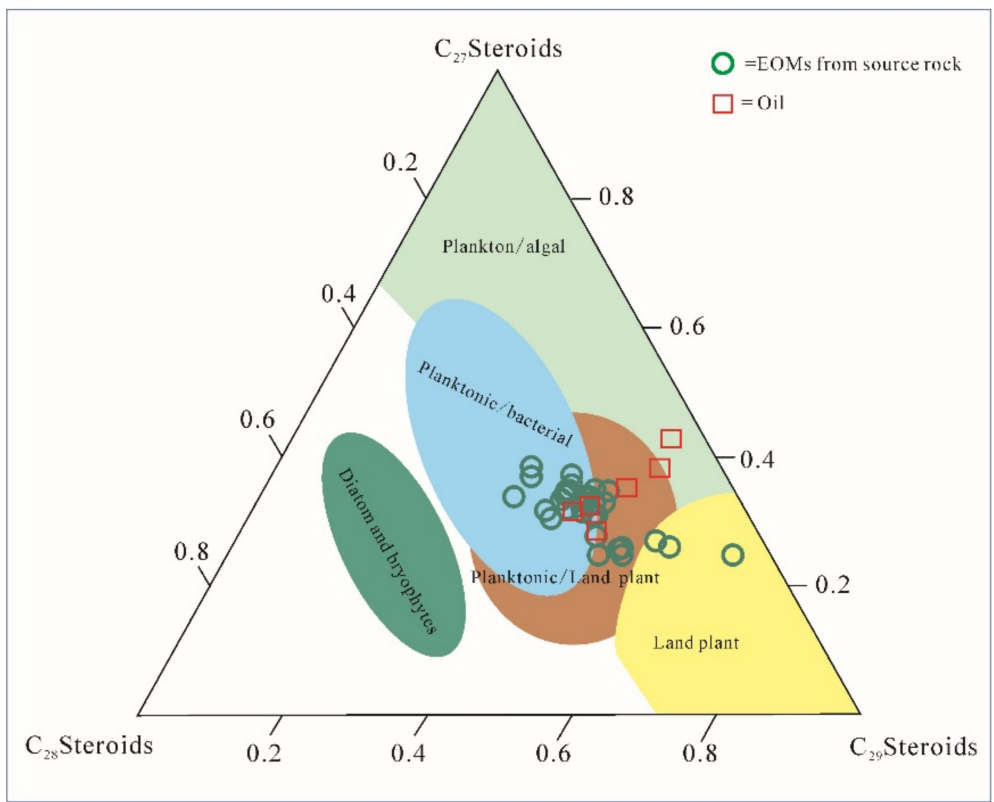

Figure 11. Ternary diagram of the relative proportions of steroids C27, C28 and C29 (the relationship between the organic matter input and the depositional environment [33].

Previous studies have found that the conventional steroids $C_{27}, C_{28}$ and $C_{29}$ are all specific to different sources of organic matter, and the relative proportions among them can be used to study the contribution of various types of organic matter in shale oil [33]. 
The relative proportions of the steroids $C_{27}, C_{28}$ and $C_{29}\left(C_{29}: 33.70-60.9 \%\right.$, average $46.08 \%$; $\mathrm{C}_{28}: 8.5-26.4 \%$, average $21.07 \%$; and $\mathrm{C}_{27}: 25.04-41.59 \%$, average $32.67 \%$; Table 4; Figure 11 ) were calculated in the Hengtongshan Formation. Previous studies on the sources of the steroids $\mathrm{C}_{27}, \mathrm{C}_{28}$ and $\mathrm{C}_{29}$ have found that $\mathrm{C}_{27}$ steroids are from zooplankton and red algae; $C_{28}$ steroids are believed to be from diatoms, green algae and higher plants; and $C_{29}$ steroids are from higher plants, some brown algae and green algae [18,33-35]. According to the relative contents of $\mathrm{C}_{27}, \mathrm{C}_{28}$ and $\mathrm{C}_{29}$ steroids, it is speculated that the samples in this study are dominated by plankton and higher plants and may be mixed with some marine organic matter.

The ratio of $22 \mathrm{~S} /(22 \mathrm{R}+22 \mathrm{~S})$ for $\mathrm{C}_{32} 17 \mathrm{a}(\mathrm{H}), 21 \mathrm{~b}(\mathrm{H})$-hopanes varies from 0.51 to 0.67 (average 0.57), showing that it is close to equilibrium. The $20 \mathrm{~S} /(20 \mathrm{~S}+20 \mathrm{R})$ and $\beta \beta /(\alpha \alpha+\beta \beta) C_{29}$ sterane ratios range from 0.3 to 0.51 (average 0.38 ) and from 0.35 to 0.63 (average 0.49), indicating that the organic matter has matured [16] (Table 4).

\subsection{Natural Gas Geochemical Characteristics}

The natural gas in the Tonghua Basin and the Hengtongshan Formation in the Sankeyushu depression is dominated by hydrocarbons, with a low non-hydrocarbon content (Table 5). The non-hydrocarbon gas is present at proportions of between $0.04 \%$ and $7.29 \%$ (average $2.95 \%$ ). The hydrocarbon gas is mainly methane, and the content of gases above ethane is low. The methane content is $90.06-98.53 \%$ (average $94.36 \%$ ), the ethane content is $0.75-5.52 \%$ (average $2.47 \%$ ), and the propane content is $0.02-1.08 \%$ (average $0.16 \%$ ).

Table 5. Natural gas composition results from the Hengtongshan Formation.

\begin{tabular}{|c|c|c|c|c|c|c|c|}
\hline Depth (m) & TG (\%) & C1 (\%) & C2 (\%) & C3 (\%) & $\operatorname{In}(\mathrm{c} 1 / \mathrm{c} 2)$ & $\operatorname{In}(\mathrm{c} 2 / \mathrm{c} 3)$ & Non-Hydrocarbon (\%) \\
\hline 222 & 1.29 & 1.27 & 0.01 & 0.00 & 4.57 & 2.39 & 0.01 \\
\hline 224 & 1.20 & 1.17 & 0.01 & 0.00 & 4.66 & 2.22 & 0.01 \\
\hline 237 & 1.02 & 0.93 & 0.02 & 0.00 & 3.90 & 4.12 & 0.07 \\
\hline 249 & 1.56 & 1.43 & 0.02 & 0.00 & 4.31 & 2.17 & 0.07 \\
\hline 250 & 1.74 & 1.64 & 0.04 & 0.00 & 3.63 & 2.32 & 0.03 \\
\hline 253 & 1.59 & 1.45 & 0.07 & 0.01 & 2.99 & 2.22 & 0.03 \\
\hline 257 & 1.35 & 1.29 & 0.04 & 0.00 & 3.45 & 2.43 & 0.01 \\
\hline 258 & 2.81 & 2.70 & 0.08 & 0.00 & 3.50 & 2.85 & 0.01 \\
\hline 259 & 0.56 & 0.52 & 0.02 & 0.00 & 3.05 & 2.94 & 0.01 \\
\hline 260 & 1.20 & 1.15 & 0.04 & 0.00 & 3.35 & 2.87 & 0.01 \\
\hline 264 & 0.83 & 0.76 & 0.04 & 0.00 & 2.92 & 3.45 & 0.03 \\
\hline 265 & 2.10 & 2.07 & 0.02 & 0.00 & 4.46 & 2.01 & 0.00 \\
\hline 268 & 2.28 & 2.18 & 0.07 & 0.01 & 3.40 & 2.42 & 0.01 \\
\hline 271 & 1.22 & 1.13 & 0.06 & 0.00 & 3.02 & 2.82 & 0.03 \\
\hline 272 & 1.38 & 1.31 & 0.06 & 0.00 & 3.04 & 3.30 & 0.00 \\
\hline 273 & 0.41 & 0.37 & 0.01 & 0.00 & 3.56 & 2.36 & 0.06 \\
\hline 274 & 2.89 & 2.75 & 0.11 & 0.00 & 3.26 & 3.08 & 0.01 \\
\hline 275 & 3.22 & 3.17 & 0.04 & 0.00 & 4.35 & 3.71 & 0.00 \\
\hline 277 & 2.32 & 2.14 & 0.08 & 0.00 & 3.25 & 3.35 & 0.04 \\
\hline 278 & 3.86 & 3.77 & 0.07 & 0.00 & 3.95 & 3.64 & 0.01 \\
\hline 284 & 1.98 & 1.87 & 0.06 & 0.00 & 3.41 & 3.43 & 0.03 \\
\hline 285 & 0.96 & 0.87 & 0.01 & 0.00 & 4.10 & 1.68 & 0.07 \\
\hline 287 & 1.06 & 1.01 & 0.02 & 0.00 & 3.95 & 1.80 & 0.02 \\
\hline 288 & 1.37 & 1.32 & 0.02 & 0.00 & 4.48 & 2.07 & 0.02 \\
\hline 295 & 0.94 & 0.86 & 0.01 & 0.00 & 4.15 & 2.35 & 0.07 \\
\hline 296 & 2.89 & 2.79 & 0.05 & 0.00 & 3.98 & 2.96 & 0.01 \\
\hline 297 & 2.36 & 2.29 & 0.02 & 0.00 & 4.86 & 2.09 & 0.02 \\
\hline 308 & 1.14 & 1.04 & 0.01 & 0.00 & 4.42 & 2.43 & 0.07 \\
\hline 311 & 2.21 & 2.06 & 0.02 & 0.00 & 4.54 & 2.25 & 0.06 \\
\hline 316 & 6.16 & 5.91 & 0.08 & 0.01 & 4.29 & 2.44 & 0.02 \\
\hline 321 & 6.24 & 5.91 & 0.11 & 0.01 & 3.97 & 2.52 & 0.03 \\
\hline 325 & 1.56 & 1.48 & 0.02 & 0.00 & 4.46 & 2.31 & 0.04 \\
\hline 326 & 0.92 & 0.85 & 0.01 & 0.00 & 4.44 & 2.41 & 0.06 \\
\hline 327 & 1.64 & 1.54 & 0.02 & 0.00 & 4.56 & 2.04 & 0.05 \\
\hline 328 & 2.27 & 2.16 & 0.02 & 0.00 & 4.77 & 2.00 & 0.04 \\
\hline 329 & 2.69 & 2.58 & 0.08 & 0.00 & 3.53 & 2.90 & 0.01 \\
\hline 331 & 3.33 & 3.25 & 0.08 & 0.00 & 3.70 & 2.91 & 0.00 \\
\hline 334 & 3.35 & 3.18 & 0.07 & 0.00 & 3.85 & 3.15 & 0.03 \\
\hline
\end{tabular}


Table 5. Cont.

\begin{tabular}{|c|c|c|c|c|c|c|c|}
\hline Depth (m) & TG (\%) & C1 (\%) & C2 (\%) & C3 (\%) & $\operatorname{In}(\mathrm{c} 1 / \mathrm{c} 2)$ & $\operatorname{In}(\mathrm{c} 2 / \mathrm{c} 3)$ & Non-Hydrocarbon (\%) \\
\hline 336 & 4.74 & 4.65 & 0.07 & 0.00 & 4.24 & 3.33 & 0.01 \\
\hline 337 & 3.16 & 3.05 & 0.07 & 0.01 & 3.83 & 2.04 & 0.01 \\
\hline 339 & 5.37 & 5.08 & 0.07 & 0.00 & 4.32 & 3.18 & 0.04 \\
\hline 340 & 3.30 & 3.13 & 0.07 & 0.00 & 3.83 & 3.82 & 0.03 \\
\hline 341 & 2.53 & 2.42 & 0.07 & 0.00 & 3.56 & 3.59 & 0.02 \\
\hline 346 & 2.60 & 2.35 & 0.07 & 0.00 & 3.52 & 3.90 & 0.07 \\
\hline 350 & 3.00 & 2.88 & 0.07 & 0.00 & 3.71 & 3.30 & 0.02 \\
\hline 351 & 3.86 & 3.60 & 0.07 & 0.01 & 3.98 & 2.03 & 0.05 \\
\hline 352 & 1.27 & 1.19 & 0.07 & 0.00 & 2.83 & 2.98 & 0.01 \\
\hline 354 & 1.53 & 1.43 & 0.07 & 0.00 & 3.01 & 2.84 & 0.02 \\
\hline 355 & 2.73 & 2.46 & 0.07 & 0.00 & 3.55 & 2.84 & 0.07 \\
\hline 357 & 1.54 & 1.43 & 0.07 & 0.01 & 3.03 & 2.05 & 0.02 \\
\hline 358 & 1.66 & 1.53 & 0.07 & 0.00 & 3.12 & 2.67 & 0.04 \\
\hline 360 & 1.59 & 1.49 & 0.07 & 0.02 & 3.06 & 1.41 & 0.00 \\
\hline 363 & 4.01 & 3.83 & 0.07 & 0.01 & 3.98 & 2.49 & 0.03 \\
\hline 376 & 2.83 & 2.63 & 0.07 & 0.00 & 3.68 & 3.32 & 0.04 \\
\hline 379 & 1.67 & 1.58 & 0.07 & 0.00 & 3.16 & 3.86 & 0.02 \\
\hline 383 & 3.07 & 2.90 & 0.07 & 0.00 & 3.78 & 4.20 & 0.03 \\
\hline 384 & 3.57 & 3.40 & 0.07 & 0.00 & 3.94 & 3.27 & 0.03 \\
\hline 386 & 1.16 & 1.06 & 0.02 & 0.00 & 3.91 & 3.06 & 0.06 \\
\hline 387 & 4.03 & 3.79 & 0.07 & 0.00 & 4.04 & 4.20 & 0.04 \\
\hline 388 & 4.12 & 3.96 & 0.07 & 0.00 & 4.08 & 4.20 & 0.02 \\
\hline 389 & 1.34 & 1.24 & 0.03 & 0.00 & 3.75 & 3.37 & 0.05 \\
\hline 390 & 5.08 & 4.90 & 0.07 & 0.00 & 4.23 & 4.27 & 0.02 \\
\hline 391 & 1.72 & 1.61 & 0.07 & 0.00 & 3.16 & 4.23 & 0.02 \\
\hline 392 & 5.80 & 5.42 & 0.07 & 0.00 & 4.32 & 4.27 & 0.05 \\
\hline 395 & 1.33 & 1.23 & 0.07 & 0.00 & 2.93 & 4.19 & 0.02 \\
\hline 396 & 3.23 & 3.13 & 0.07 & 0.00 & 3.79 & 4.26 & 0.01 \\
\hline 397 & 1.33 & 1.21 & 0.03 & 0.00 & 3.64 & 3.46 & 0.07 \\
\hline 398 & 3.97 & 3.74 & 0.07 & 0.00 & 4.00 & 4.23 & 0.04 \\
\hline 399 & 2.83 & 2.68 & 0.07 & 0.00 & 3.66 & 4.24 & 0.03 \\
\hline 400 & 1.62 & 1.53 & 0.03 & 0.00 & 3.96 & 3.38 & 0.04 \\
\hline 401 & 4.01 & 3.64 & 0.07 & 0.00 & 3.97 & 4.23 & 0.07 \\
\hline 402 & 2.04 & 1.92 & 0.07 & 0.00 & 3.30 & 4.26 & 0.02 \\
\hline 403 & 1.76 & 1.66 & 0.07 & 0.00 & 3.17 & 4.24 & 0.02 \\
\hline 404 & 4.81 & 4.62 & 0.07 & 0.02 & 4.24 & 1.14 & 0.02 \\
\hline 409 & 4.37 & 4.19 & 0.17 & 0.01 & 3.21 & 3.32 & 0.00 \\
\hline 410 & 1.67 & 1.56 & 0.07 & 0.00 & 3.08 & 2.72 & 0.02 \\
\hline 411 & 1.26 & 1.17 & 0.03 & 0.00 & 3.81 & 2.43 & 0.05 \\
\hline 412 & 4.51 & 4.37 & 0.07 & 0.01 & 4.10 & 2.36 & 0.01 \\
\hline 413 & 1.62 & 1.51 & 0.07 & 0.01 & 3.04 & 2.67 & 0.02 \\
\hline 415 & 4.90 & 4.63 & 0.07 & 0.00 & 4.19 & 3.00 & 0.04 \\
\hline 416 & 1.89 & 1.77 & 0.07 & 0.00 & 3.29 & 3.16 & 0.03 \\
\hline 417 & 1.31 & 1.20 & 0.03 & 0.01 & 3.54 & 1.79 & 0.05 \\
\hline 418 & 5.23 & 5.04 & 0.16 & 0.00 & 3.47 & 4.14 & 0.01 \\
\hline 419 & 2.14 & 2.04 & 0.07 & 0.00 & 3.43 & 3.45 & 0.02 \\
\hline 420 & 3.21 & 3.02 & 0.07 & 0.01 & 3.73 & 1.62 & 0.03 \\
\hline 421 & 1.82 & 1.72 & 0.06 & 0.00 & 3.32 & 3.39 & 0.02 \\
\hline 422 & 1.75 & 1.62 & 0.07 & 0.00 & 3.21 & 3.44 & 0.03 \\
\hline 423 & 5.55 & 5.28 & 0.07 & 0.00 & 4.39 & 3.39 & 0.04 \\
\hline 424 & 1.86 & 1.73 & 0.06 & 0.00 & 3.34 & 2.78 & 0.03 \\
\hline 425 & 1.72 & 1.62 & 0.06 & 0.00 & 3.28 & 3.47 & 0.02 \\
\hline 426 & 7.23 & 7.00 & 0.08 & 0.01 & 4.44 & 2.36 & 0.02 \\
\hline 427 & 1.33 & 1.28 & 0.01 & 0.00 & 4.46 & 1.79 & 0.02 \\
\hline 428 & 1.30 & 1.18 & 0.04 & 0.01 & 3.40 & 1.76 & 0.06 \\
\hline 429 & 1.27 & 1.18 & 0.02 & 0.01 & 3.86 & 1.58 & 0.04 \\
\hline 430 & 6.56 & 6.39 & 0.06 & 0.00 & 4.60 & 3.33 & 0.02 \\
\hline
\end{tabular}




\section{Discussion}

\subsection{Oil Source Input}

The TOC/TN ratio in sedimentary rocks is an effective indicator for analyzing the source of organic matter [14]. The original protein content of microalgae in lakes is higher than that of terrestrial higher plants, so the TOC/TN ratio of aquatic phytoplankton is relatively low, usually from 4 to 10 , whereas the TOC/TN ratio of terrestrial plants is often greater than 10 [36]. Therefore, in the study of lake environments, the TOC/TN ratio is often used to determine whether the organic matter in the sediment originates from microorganisms or higher plants [36].

In this study, through systematic testing and calculation of the TOC/TN value of the source rock in the Hengtongshan Formation, it was found that the TOC/TN value of samples between 107.84 and $184.3 \mathrm{~m}$ and between 264.2 and $292.16 \mathrm{~m}$ is greater than 10 , with a maximum of 21.00. In contrast, the values in the other sections are less than 10 (Table 2). Therefore, higher plants may have made a greater contribution to the organic matter in the sediments of the first two sections. However, in terrestrial formations, organic nitrogen is easily mineralized or oxidized, and the presence of large amounts of exchangeable fixed ammonium in organic deposits in terrestrial sediments accounts for $10 \%$ of organic ammonia [37], which can result in a low TOC/TN ratio. Therefore, using this value to determine the source of organic matter is very uncertain, so in this study, biomarker compounds were used to further comprehensively determine the source of the organic matter.

Previous studies have shown that lower aquatic organisms are rich in lipid compounds, and n-alkanes are mainly composed of low carbon number components, while higher plants are often rich in wax and mainly composed of high carbon number components [16]. Therefore, the n-alkane distribution characteristics of saturated hydrocarbons can reflect the type of organic matter in source rocks. It is generally believed that the main peak carbon number is generally less than that of n-alkane $C_{23}$ and is unimodal. Additionally, the main carbon peak of higher plants is usually greater than that of $n$-alkane $C_{25}$, and the main carbon peak of mixed organic matter is between the peaks of n-alkane $\mathrm{C}_{23}$ and n-alkane $C_{25}$ [16]. In this study, it was found that the main carbon peaks of the n-alkanes in both the extracts and the shale oil in the $\mathrm{m} / \mathrm{Z} 85$ diagram are less than the peak of n-alkane $C_{23}$, which indicates that the contribution of lower aquatic organisms in organic matter is larger than that of higher plants. Steroids and hopanoids represent eukaryotic and prokaryotic contributions to the source material of sediments, respectively [27], and the average values of the steroid/hopanoid ratio in this study are $0.12-0.51$ (average 0.26 ). Low steroid/hopanoid ratios are characteristic of lacustrine or special bacterial-influenced facies [18,38], indicating strong microbial activity [16].

According to the results of $\mathrm{Pr} / \mathrm{n}-\mathrm{C}_{17}$ and $\mathrm{Ph} / \mathrm{n}-\mathrm{C}_{18}$, the source of the organic matter in the sediments of the Hengtongshan Formation may have been a mixed source (Figure 7). This is further confirmed by the relative ratio of $C_{27} C_{28} C_{29}$ sterane to $C_{27} / C_{29}$, which indicates that the source of the organic matter in the source rock in the Hengtongshan Formation was a mixed source and that plankton and higher plants were the main contributors in many samples. Combined with the trend between the sample depth and the TOC/TN value, the relative proportions of $C_{29}$ sterane in the $107.84 \sim 184.3 \mathrm{~m}$ and $235.69 \sim 292.16 \mathrm{~m}$ depth ranges are greater than $50 \%$, indicating that plankton and higher plants are dominant in the oil-related organic matter, which is consistent with the conclusion based on the TOC/TN value. As a whole, the source material of the source rock of the Hengtongshan Formation is a mixture of aquatic organisms (algae and bacteria) and higher plants and may have marine biological components.

\subsection{Maturity}

In this study, a variety of methods were used to evaluate the thermal maturity of the source rock, and a detailed maturity evaluation was carried out on the Hengtongshan Formation. According to the reflectance (\% Ro) test data of 21 samples obtained from each 
source rock horizon, the maturity of the samples is between 0.97 and 1.53 (average 1.10, Table 2), which indicates that the samples have entered the oil generation window and kerogen has begun to produce hydrocarbon compounds [18,39]. Based on the $T_{\max }$ values from a large number of samples, it was found that the $T_{\max }$ values, which are indicative of thermal maturity, are highly correlated with Ro (Figure 12). The sections between 233 and $238 \mathrm{~m}$ and between 287 and $294 \mathrm{~m}$ are of high maturity, which indicates that, compared with other sections, these sections may have suffered more intense thermal action because the kerogen has a high maturity. Combined with the geological background of the Tonghua Basin, volcanic activity may have caused these sections to have especially high thermal maturities; however, in the depositional stage of the Hengtongshan Formation, there was no large-scale and long-term strong volcanic activity $[7,8]$. Thus, local volcanic activity only caused a higher thermal effect on some strata.

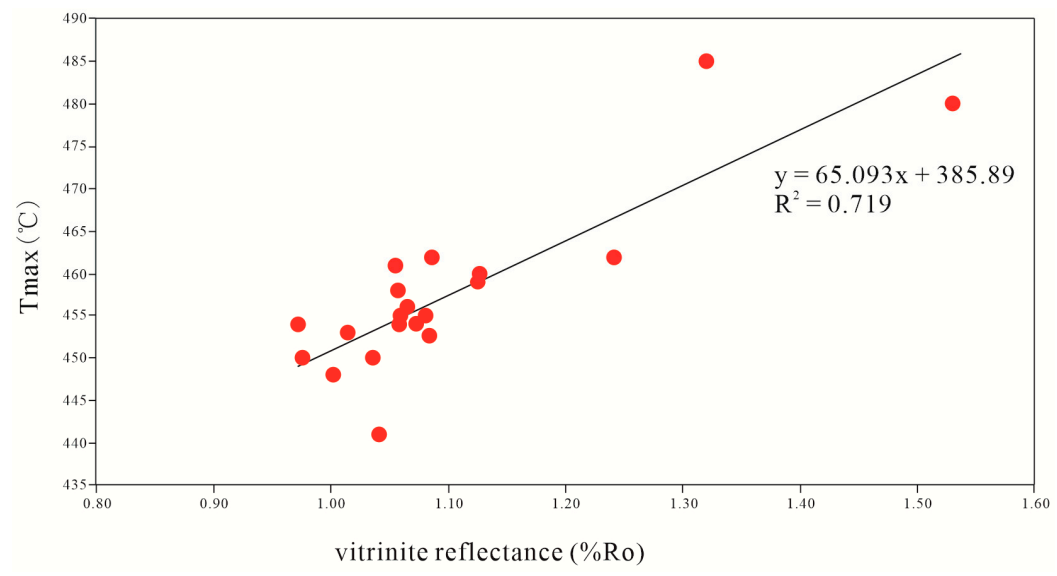

Figure 12. Plot of Ro versus pyrolysis $\mathrm{T}_{\max }$.

The biomarkers that can reflect the maturity of the organic matter in source rock extracts and shale oil, such as CPI, Ts /(Ts + Tm), $\mathrm{C}_{30} \mathrm{M} / \mathrm{C}_{30} \mathrm{H}, \mathrm{C}_{32} 17 \alpha(\mathrm{H}) 21(\mathrm{H})$-hopanes, etc., were studied. These biomarker parameters all show that the source rocks in the Hengtongshan Formation have a high thermal maturity. The correlation parameters of biomarkers in the shale oil and shale extracts are similar, and the vertical variation throughout the entire formation is not significant, indicating that hydrocarbons have been discharged from the source rock. Figures 13 and 14 also confirm that the organic matter has reached the mature and highly mature levels and the source rock has crossed the hydrocarbon generation threshold.

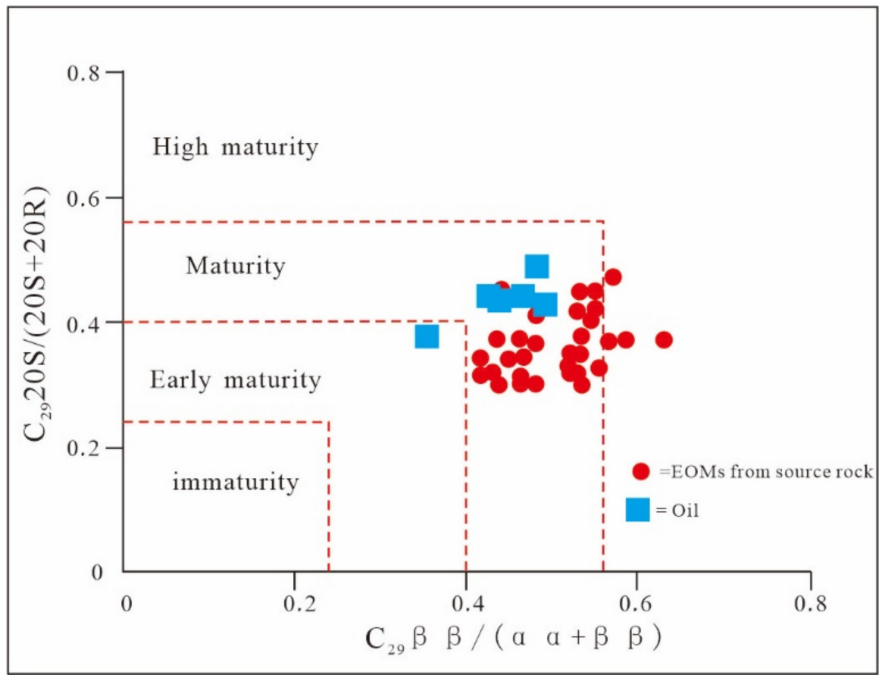

Figure 13. A cross plot of C29 sterane $20 S /(20 S+20 R)$ and C29 Sterane $\beta \beta /(\alpha \alpha+\beta \beta)$, adapted from [21]. 


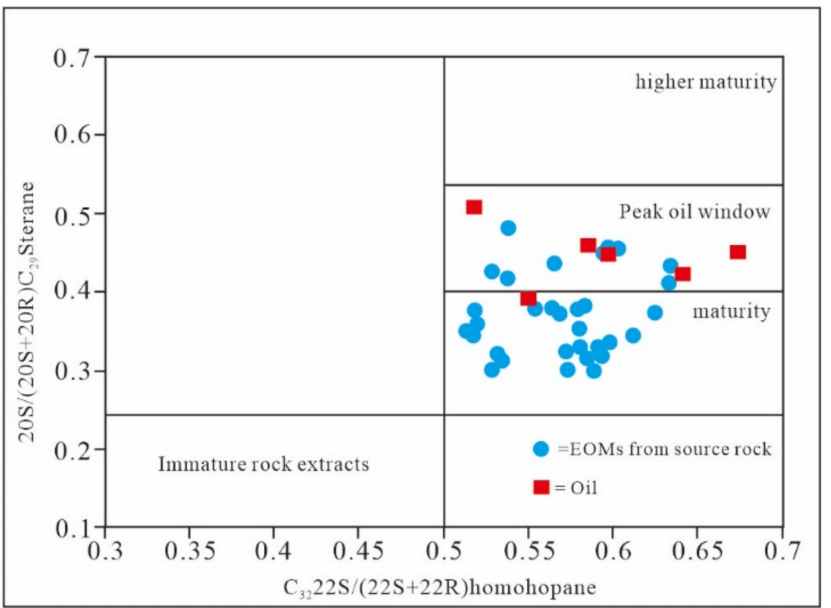

Figure 14. A cross plot of C29 sterane $20 S /(20 S+20 R)$ and C32 homohopane $22 S /(22 S+22 R)$, adapted from [21].

Kerogen can generate hydrocarbons as the thermal maturity increases, and the generated hydrocarbon gas and liquid hydrocarbons can have different molecular weights. Furthermore, hydrocarbon macromolecules can be heated further in the process of pyrolysis to produce solid asphalt and a large amount of pyrolysis gas [18]. The natural gas in the Hengtongshan Formation is mainly composed of methane and a small amount of ethane and propane. The methane content accounts for $90.06-98.53 \%$, with an average of $94.36 \%$. The gas is not dry gas. According to the interaction diagram of $\mathrm{InC}_{1} / \mathrm{C}_{2}$ and $\mathrm{InC}_{2} / \mathrm{C}_{3}$, the gas may be a mixture of kerogen degradation gas and oil cracking gas, and most of the gas was produced when the Ro exceeded $1.5 \%$ (Figure 15).

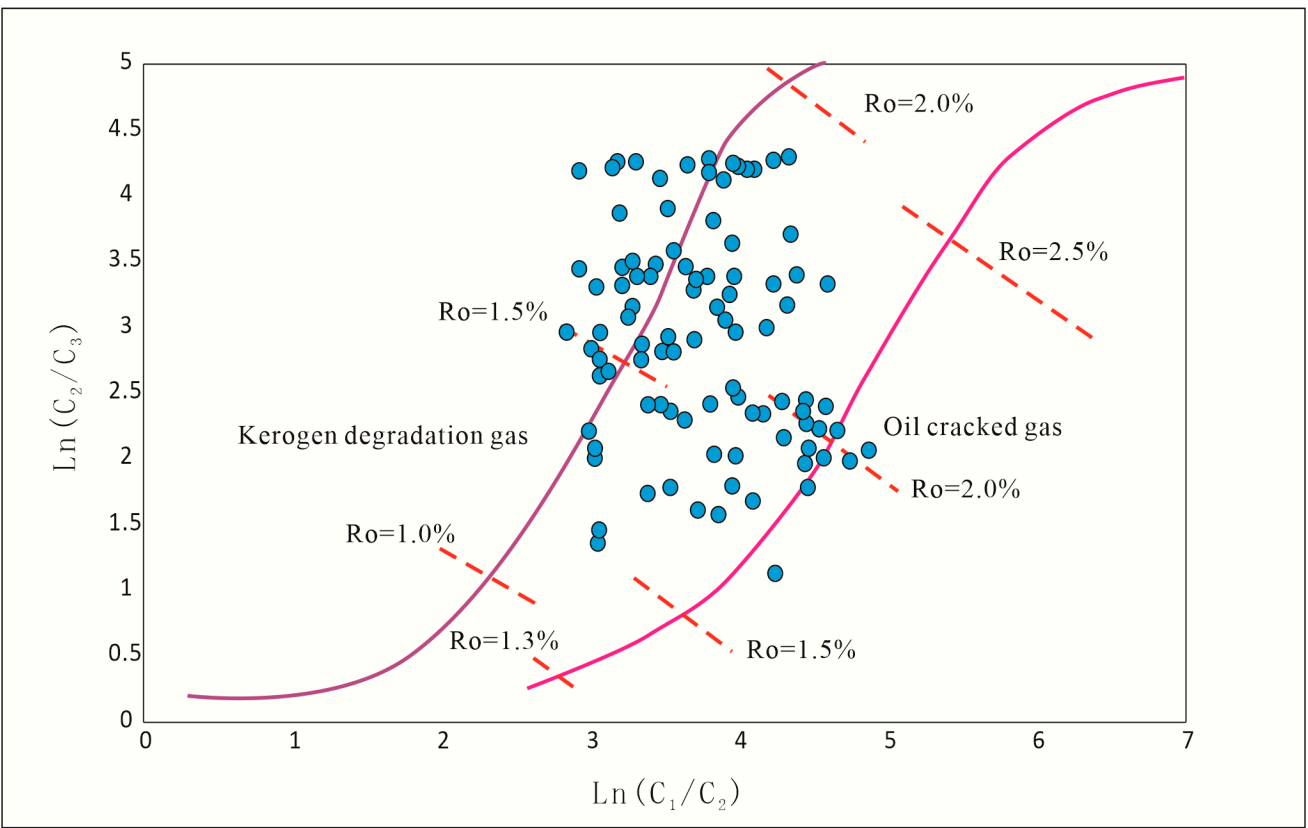

Figure 15. Recognition plate of natural gas in the Tonghua Basin, adapted from [40].

\subsection{Depositional Environment}

The Hengtongshan Formation was deposited in the warm and moist Early Cretaceous, and there was no large-scale tectonic activity in the basin during this period $[1,5,9,10]$. According to previous studies, during the depositional period of the Hengtongshan Formation, only occasional small-scale volcanic activity occurred near the faults in the Tonghua Basin, resulting in a basin-wide, relatively quiescent stage, and sediments were deposited 
under a humid and warm climate [7,37]. The volcanic activity released a large amount of gas at the bottom of the lake basin, causing stratification of water masses. Reducing environments provide good conditions for preserving organic matter in the sediment, and volcanic activity can release some nutrients, stimulating the growth of microorganisms at the bottom of the lake and, therefore, increasing the accumulation of organic matter. Through maps of $\mathrm{Pr} / \mathrm{Ph}$ and $\mathrm{Pr} / \mathrm{n}-\mathrm{C}_{17}$ vs. $\mathrm{Ph} / \mathrm{n}-\mathrm{C}_{18}$, it can be shown that the organic matter was deposited under anoxic conditions, and the change in the TOC value in the vertical direction demonstrates that the organic matter has been enriched and preserved (Figure 1). Figures 9 and 10 also show that the aquatic environment of the Hengtongshan Formation during the depositional period was a kind of saltwater environment, and some strata show the characteristics of marine strata. In the discussion of organic matter, it is also suspected that the source rocks of the Hengtongshan Formation include marine organic matter.

Previous researchers have also used the TS content in sedimentary strata to determine whether the formation environment was a marine environment or a freshwater lake environment. A high TS content often indicates that the sediments formed in a marine environment, while a low sulfur content often indicates that the sediments formed in a continental lake environment [41,42]. The TS values of the samples in this study show that most of the samples formed in a continental lake sedimentary environment and that a small number of samples formed in a marine sedimentary environment (Figure 16). Combined with the observations of the sedimentary facies, these findings also indicate a continental origin, and the inclusion of marine organic matter components may be the result of a short-term transgression.

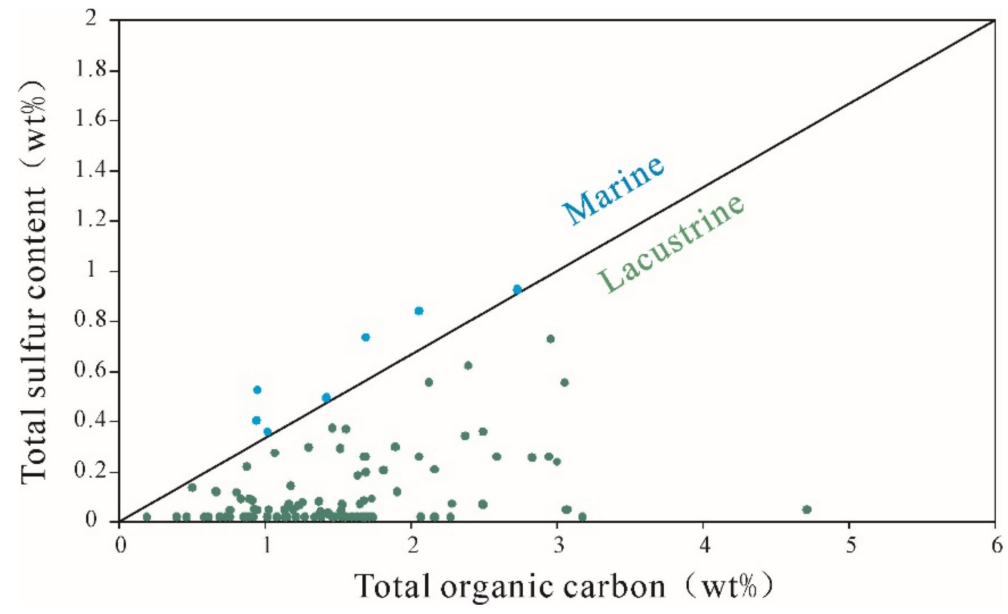

Figure 16. Total sulfur content versus TOC, adapted [42].

\subsection{Resource Potential of the Shale Oil}

A large number of TOC and pyrolysis evaluation tests on the source rocks in the Hengtongshan Formation show that the TOC contents of the three members of the formation are quite different. The hydrocarbon-generating ability of the source rocks in the Hengtongshan Formation was studied using pyrolysis data. Previous studies have shown that sample HI values higher than $300 \mathrm{mg} \mathrm{HC} / \mathrm{g}$ TOC and high TOC contents (>1 wt \%) will produce oil [2]. The second member is obviously better than the first and third members, with an average TOC of $1.37 \%$ and an S2 of 7.34. Most of the samples are classified as good and very good source rocks [43] (Table 2, Figure 17). The relationship among the TOC content, EOM and hydrocarbon production (Table 3 and Figure 18) shows that the sediments in the second member are classified as good to very good source rocks with a good oil production potential [43]. This paper discusses the maturity of the source rocks in the Hengtongshan Formation and concludes that the source rocks have crossed the threshold of hydrocarbon generation. Table 1 shows that the content of brittle minerals 
(quartz + carbonate) in the formation is relatively high, with an average of $50.61 \%$, which is also favorable for oil exploitation. The comprehensive analysis shows that the Hengtongshan Formation may be rich in shale oil and natural gas, while the second member can be regarded as a potential production stratum.

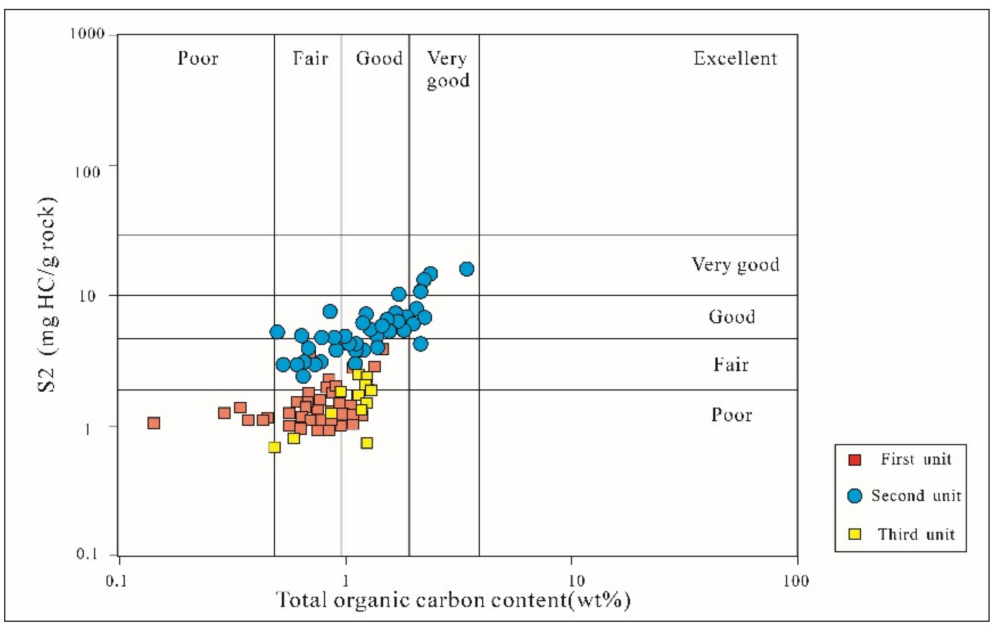

Figure 17. S2 and TOC diagrams showing the source rock potential, adapted from [43].

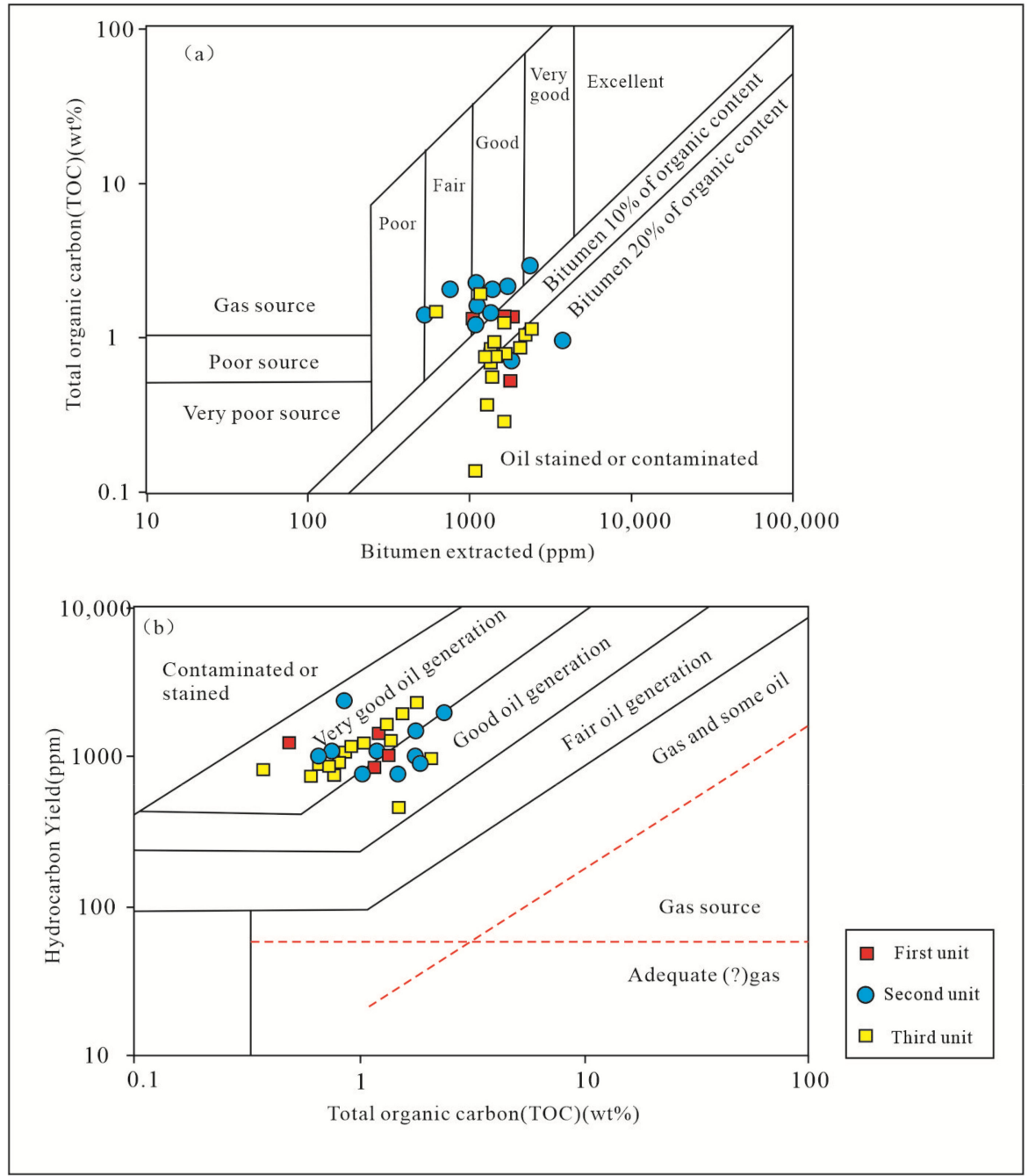

Figure 18. (a) Plots of TOC versus bitumen extract showing source potential rating and (b) plots of TOC versus hydrocarbon yield, adapted from [44]. 


\section{Conclusions}

The Hengtongshan Formation in the Tonghua Basin in Northeastern China is an important shale oil- and gas-bearing horizon. In this paper, through systematic sampling of the Hengtongshan Formation in the Sankeyushu depression of the Tonghua Basin, observations of the petrology and organic petrology and a study of the geochemical characteristics, we found that the Hengtongshan Formation has the following characteristics.

The Hengtongshan Formation is mainly composed of black shale and contains a small amount of plant fossils and thin-layered volcanic rocks. The content of brittle minerals (quartz + carbonate) is high, with an average of $50.61 \%$, and the content of clay is $38.62 \%$. The organic matter of the Hengtongshan Formation has the characteristics of lacustrine or special bacteria-influenced facies. On the whole, the source material of the source rock of the Hengtongshan Formation is a kind of mixture of aquatic organisms (algal and bacteria) and higher plants, and some geochemical parameters also indicate that the organic matter in the formation may include some marine organic matter.

The organic matter in the Hengtongshan Formation was deposited in a saline, reducing environment, which was conducive to the enrichment and preservation of the organic matter. Volcanism may have promoted the formation of this reducing environment in different water layers at the bottom of the lake, while a short-term transgression may have led to the saltiness of the lake water.

The maturity of the organic matter in all the source rocks in the Hengtongshan Formation is relatively high and has entered the oil generation window, resulting in the generation of a large amount of hydrocarbons. During the drilling process, shale oil and natural gas were also encountered. The source rocks at 233-238 m and 287-294 m are overmature, which may be due to the volcanic process leading to enhanced thermal processes in some strata.

Through a large number of TOC and pyrolysis evaluation tests, we found that the second member of the formation is obviously superior to the first and third members, with an average TOC of $1.37 \%$ and an average HI of $560.93 \mathrm{mg} \mathrm{HC} / \mathrm{g}$ TOC. Most of the samples can be categorized as good to very good source rocks with a good resource potential. Based on the shale oil and natural gas encountered in the process of drilling, it is predicted that the shale oil is present in the form of a self-sourced reservoir, but the migration range of natural gas may have been relatively large. The comprehensive analysis shows that the Hengtongshan Formation may be rich in shale oil and natural gas, and the second member can be regarded as a potential production horizon.

Author Contributions: Y.S. and X.S. provided the data and funding. W.H. and X.S. wrote the paper and analyzed the data. All authors have read and agreed to the published version of the manuscript.

Funding: This research was funded by the self-determined Foundation of the Key Laboratory of Oil Shale and Coexistent Energy Minerals of Jilin Province (Grant No. YYY-ZZ-18-03), the National Nature Science Foundation of China (Grant No. 41790453, 41972313 and 41903067) the Key Laboratory for the Evolution of Past Life and Environment in Northeast Asia, Ministry of Education, Jilin University, and the Engineering Research Center of Geothermal Resources Development Technology and Equipment, Ministry of Education, Jilin University.

Acknowledgments: Thanks to Ms. Chenyang Wu for her contribution and assistance to this study.

Conflicts of Interest: The authors declare no conflict of interest.

\section{References}

1. Dandan, W.; Xingui, Z.; Shizhen, L.; Wenhao, Z.; Weibin, L.; Yanhua, L. Petroleum geologic features and generation potential of the Lower Cretaceous hydrocarbon source rocks in the Tonghua Basin. Acta Geol. Sin. 2017, 91, 2119-2130. (In Chinese with English abstract)

2. Hunt, J.M. Petroleum Geochemistry and Geology, 2nd ed.; W.H. Freeman and Company: San Francisco, CA, USA, $1996 ;$ p. 743.

3. Yubo, W.; Kan, G.; Dingding, L.; Yang, W. Mineral resources evaluation and status, important metallogenic belt and the dominant mineral resource potential of Tonghua City, Jilin Province. Jilin Geol. 2011, 30, 137-144. (In Chinese with English abstract) 
4. Xinpeng, H.; Guoli, H.; Chao, L.; Yanbo, L.I.; Changcheng, L. Petroleum geologic features and petroleum resources potential in Tonghua Basin. Glob. Geol. 2013, 32, 337-343. (In Chinese with English abstract)

5. Shan, X.; Du, S.; Guo, X. Characteristics and evaluation of the high-quality source rocks of cretaceous continental shale oil in Tonghua Basin. Acta Geol. Sin. 2019, 93, 146-154. [CrossRef]

6. Bingyi, Z.; Xiaodong, Z. Paleoproterozoic strata sequence and tectonic setting in southern Jilin Province. Glob. Geol 2009, 28, 424-429. (In Chinese with English abstract)

7. Guangming, Z. Petroleum Geology of China 1996, Volume 1, p. 5122013517.

8. Dongjin, L.; Penji, Z.; Chuntian, Z.N.L.; Jiaru, S.; Penji, C.; Fengzhen, M. Evolution and changes of faunas across Jurassic Cretaceous boundary at Sankeyushu, Tonghua, Jilin. Acta Palaeontol. Sin. 1998, 27, 684-693. (In Chinese with English abstract)

9. Yueqiao, Z.; Shuwen, D.; Yue, Z. Jurassic tectonics of North China: A synthetic view. Acta Geol. Sin 2007, 81, 142-148, (In Chinese with English abstract). [CrossRef]

10. Chengdong, Q.; Yujing, P.; Changjian, Y.; Xiaoping, L.; Xiaodong, Z. Relationship of granite type with basin evolution and its metallogenetic specialization of Global Province in Late Triassic-Early Cretaceous. Glob. Geol 2009, 28, 166-170. (In Chinese with English abstract)

11. Nesbitt, H.W.; Markovics, G. Weathering of granodioritic crust, longterm storage of elements in weathering profiles, and petrogenesis of siliciclastic sediments. Geochim. Cosmochim. Acta 1997, 61, 1653-1670. [CrossRef]

12. Tissot, B.P.; Welte, D.H. Petroleum Formation and Occurrence; Springer-Verlag: Berlin, Germany, 1978; pp. 1-554.

13. Hunt, J.M. Petroleum Geoehemistry and Geology, 1st ed.; W.H. Freeman and Company: New York, NY, USA, $1979 ;$ pp. $261-273$.

14. Krishnamurthy, R.V.; Bhattacharya, S.K.; Kusumgar, S. Palaeoclimatic changs deduced from $13 \mathrm{C} / 12 \mathrm{C}$ and C/N ratios of Karewa Lake sediments, India. Nature 1986, 323, 150-152. [CrossRef]

15. Mustapha, K.A.; Abdullah, W.H. Petroleum source rock evaluation of the Sebahat and Ganduman Formations, Dent Peninsula, Eastern Sabah, Malaysia. J. Asian Earth Sci. 2013, 76, 346-355. [CrossRef]

16. Peters, K.E.; Walters, C.C.; Moldowan, J.M. The Biomarker Guide. Biomarkers and Isotopes in Petroleum Exploration and Earth History. Cambridge University Press: New York, NY, USA, 2005; Volumes 1 and 2.

17. Baker, D.R. Organic geochemistry and geological interpretations. J. Geol. Edu. 1972, 20, 221-234. [CrossRef]

18. Tissot, B.P.; Welte, D.H. Petroleum Formation and Occurrence; Springer-Verlag: Berlin, Germany, $1984 ;$ p. 699.

19. Powell, T.G.; Mckirdy, D.M. Relationship between ratio of pristane to phytane, crude oil composition and geological environment in Australia. Nature Phys. Sci. 1973, 243, 37-39. [CrossRef]

20. Chandra, K.; Mishra, C.S.; Samanta, U.; Gupta, A.; Mehrotra, K.L. Correlation of different maturity parameters in the AhmedabadMehsana block of the Cambay basin. Org. Geochem. 1994, 21, 313-321. [CrossRef]

21. Peters, K.E.; Moldowan, J.M. The Biomarker Guide: Interpreting Molecular Fossils in Petroleum and Ancient Sediments. Choice Reviews Online; Prentice Hall: Englewood Cliffs, NJ, USA, 1993; Volume 30, pp. 30-2690.

22. Lijmbach, G.W. On the origin of Petroleum. In Proceedings of the 9th World Petroleum Congress 2, Tokyo, Japan, 11-16 May; Applied Science Publishers: London, UK, 1975; pp. 357-369.

23. Shanmugam, G. Significance of coniferous rainforests and related organic matter in generating commercial quantities of oil, Gipps-land Basin, Australia. Am. Assoc. Pet. Geol. Bull. 1985, 69, 1241-1254.

24. Makeen, Y.M.; Abdullah, W.H.; Hakimi, M.H. Biological markers and organic petrology study of organic matter in the Lower Cretaceous Abu Gabra sediments (Muglad Basin, Sudan): Origin, type and palaeoenvironmental conditions. Arab. J. Geosci. 2015, 8, 489-506. [CrossRef]

25. Makeen, Y.M.; Abdullah, W.H.; Hakimi, M.H. The origin, type and preservation of organic matter of the Barremiane Aptian organic-rich shales in the Muglad Basin, Southern Sudan, and their relation to paleoenvironmental and paleoclimate conditions. Mar. Petrol. Geol. 2015, 65, 187-197. [CrossRef]

26. Makeen, Y.M.; Abdullah, W.H.; Hakimi, M.H.; Elhassan, O.M.A. Organic geochemical characteristics of the lower Cretaceous Abu Gabra formation in the great Moga oilfield, Muglad Basin, Sudan: Implications for depositional environment and oil-generation potential. J. Afr. Earth Sci. 2015, 103, 102-112. [CrossRef]

27. Peters, K.E.; Walters, C.C.; Moldowan, J.M. The Biomarker Guide; Cambridge University Press: Cambridge, UK, 2004.

28. Qin, J.; Wang, S.; Sanei, H.; Jiang, C.; Chen, Z.; Ren, S.; Xu, X.; Yang, J.; Zhong, N. Revelation of organic matter sources and sedimentary environment characteristics for shale gas formation by petrographic analysis of middle Jurassic Dameigou formation, northern Qaidam Basin, China. Int. J. Coal Geol. 2018, 195, 373-385. [CrossRef]

29. Gürgey, K. Geochemical characteristics and thermal maturity of oils from the Thrace Basin (western Turkey) and western Turkmenistan. J. Pet. Geol 1999, 22, 167-189.

30. Brassell, S.C.; McEvoy, J.; Hoffman, C.F.; Lamb, N.A.; Peakman, T.M.; Maxwell, J.R. Isomerisation rearrangement and aromatisation of steroids in distinguishing early stages of diagenesis. Org. Geochem. 1984, 6, 11-23. [CrossRef]

31. Seifert, W.K.; Moldowan, J.M. Applications of steranes, terpanes and monoaromatics to the maturation, migration and source of crude oils. Geochim. Cosmochim. Acta 1978, 42, 77-95. [CrossRef]

32. Sinninghe-Damste, J.S.; Kenig, F.; Koopmans, M.P.; Koster, J.; Schouten, S.; Hayes, J.M.; De Leeuw, J.W. Evidence for gammacerane as an indicator of water column stratification. Geochim. Cosmochim. Actavol 1995, 59, 1895-1900. [CrossRef]

33. Huang, W.Y.; Meinschein, W.G. Sterols as ecological indicators. Geochim. Cosmochim. Acta 1979, 43, 739-745. [CrossRef] 
34. Volkman, J.K.; Maxwell, J.R. Acyclic isoprenoids as biological markers. In Biological Markers in the Sedimentary Record; Johns, R.B., Ed.; Elsevier: Amsterdam, The Netherlands, 1986; pp. 1-42.

35. Mackenzie, A.S.; Patience, R.L.; Maxwell, J.R.; Vandenbroucke, M.; Durand, B. Molecular parameters of maturation in the Toarcian shales, Paris Basin, France I. Changes in the configurations of acyclic isoprenoid alkanes, steranes, and triterpanes. Geochim. Cosmochim. Acta 1980, 44, 1709-1721. [CrossRef]

36. Finlay, J.C.; Kendall, C. Stable isotope tracing of temporal and spatial variability in organic matter sources to freshwater ecosystems. In Stable Isotopes in Ecology and Environmental Science, 2nd ed.; Michener, R., Lajtha, K., Eds.; Blackwell Publishing: Oxford, UK, 2007; pp. 283-333.

37. Li, Z.Y.; Jia, G.D. Separation of total nitrogen into organic and inorganic forms from sediments for isotopic analysis. Org. Gechem. 2011, 42, 296-299. [CrossRef]

38. Bechtel, A.; Gratzer, R.; Sachsenhofer, R.F. Chemical characteristics of upper cretaceous (Turonian) jet of the Gosau group of Gams/Hieflau (Styria, Austria). Int. J. Coal Geol. 2001, 46, 27-49. [CrossRef]

39. Bordenave, M.L. Applied Petroleum Geochemistry; Technip: Paris, France, 1993.

40. Xie, Z.Y.; Li, Z.S.; Wei, G.Q.; Li, J.; Wang, D.L.; Wang, Z.H.; Dong, C.Y. Experimental research on the potential of sapropelic kerogen degradation gas and discrimination of oil cracking gas. J. Nat. Gas Geosci. 2016, 27, 1057-1066. [CrossRef]

41. Berner, R.A.; Raiswell, R. Burial of organic carbon and pyrite sulfur in sediments over Phanerozoic time: A new theory. Geochim. Cosmochim. Acta 1983, 47, 855-862. [CrossRef]

42. Mohialdeen, I.M.J.; Hakimi, M.H.; Al-Beyati, F.M. Geochemical and petrographic characterization of Late Jurassic-Early Cretaceous Chia Gara Formation in Northern Iraq: Palaeoenvironment and oil-generation potential. Mar. Petrol. Geol. 2013. [CrossRef]

43. Peters, K.E.; Cassa, M.R. Applied source rock geochemistry. In The Petroleum System-From Source to Trap; Magoon, L.B., Dow, W.G., Eds.; American Association of Petroleum Geologists Memoir: Tulsa, OK, USA, 1994; Volume 60, pp. 93-120.

44. Othman, R.S. Petroleum Geology of Gunnedah-Bowen-Surat Basins, Northern New Wales (Stratigraphy, Organic Petrology and Organic Geochemistry). Ph.D. Thesis, University of New South Wales, Kensington, Australia, 2003; p. 312. 